\title{
Risk Assessment of BOT Road Projects
}

\author{
Engineer Rinaj Pathan ${ }^{1} \&$ Prof. Dr. S. S. Pimplikar ${ }^{2}$ \\ (CivilDepartment,M.I.T.College of Engineering, PaudRoad, Pune 411038/University of Pune, India)
}

\begin{abstract}
To assess the risks involved in BOT by studying a specific case of BOT Road Project, To evaluate the role of financial stability on the project and the subsequent effect on risks. To Study the individualistic approach of the involved parties...

BOT has been one of the recent innovations in project finance. The Build-Operate-Transfer (BOT) scheme is a limited recourse financing technique. Many have adopted this approach as an alternative to traditional public financing for infrastructure development projects.

It examines the type of capital and debt in project financing. In addition, it examines the financial instruments used in project financing. Due to lack of fund availability, government had taken decision to implement the project of Major Bridge across river along with bypass route outside city through BOT. This BOTwas purely based on concession period. Tender has specific clause which affects the rate of interest due to change in prime lending rate issued by State bank of India. There is wide range of fluctuation in PLR from start of project \&up till now. So, concession period is changed according to that.

This paper mainly representing the risk of financing in operation period due to fluctuation in prime lending rate.

Key Words: Bot, Cash Flow, Concession Period, Finance Risk, Plr, Ppp
\end{abstract}

\section{Introduction}

India is a developing country and transportation forms the backbone of the Indian economy. Rail transport is the most used system for long range and large quantity commodity transport. However, it has some limitations. Road transport is therefore an essential assistance system which is extremely well designed, due to which transport closest to the drop point is possible. Road transport efficiency depends on several factors like availability of fuel point locations, vicinity etc. but the most important of all these is the quality and subsequent services. Road construction forms an integral part of infrastructure development. Most of the times, the largescale projects like road development were taken up by the Government solely, however, this increased the financial as well as labour stress on the Government bodies. Therefore, an alternative arrangement in the form of Private Participation Projects (Public Private Participation) under the headings like Build - Operate - Transfer (BOT) can be applicable.

In the process of the financing planning, there are many assessment methods such as NPV (net present value), BCA (benefit cost analysis), IRR (internal rate of return) and PBY (pay back year) can be used to evaluate the financing project of the BOT projects (Finnerty, 1996).

BOTmechanism plays a vital role in the infrastructural development by

- Reducing financial burden on the Government.

- Assisting completion of the project in time.

- Enhances service quality and efficiency.

- Delivering better value of money proposition.

- Transparency and impartiality in the process of inviting private participation.

- Sharing the risks between Government and contractors.

Risks are an integral part of any activity. They can be in very small amounts when the projects / activities are well planned and the possible errors accounted for. However, when no such attention to details is paid, risks can increase, Risk assessment is a good method for such problems where a separate task for studying the projects and evaluating the possible loopholes which may be converted to risks is taken up.BOT projects involve the participation of two or more Governing bodies, thereby resulting in more than one plans of action. These action plans are based on individual experiences of the involved parties and therefore may not be similar to each other. Simultaneously, this results in uneven evaluation of the possible risks. There are several other reasons which can also play a crucial role in assessment of BOT projects like

- Improper decision making

- Negligence towards risks

- Misinterpretation by users

- Political influence 
Risks at Different Stages of A PPP Project

An infrastructure project typically faces risks throughout project period, which has to mitigate to enable financing on a limited project recourse basis. The types of risks are several at the different at each stage of the project and hence need to be mitigated appropriately.

\subsection{1) Project Start - up phase}

During this phase, equipment is tested, raw material inputs are ordered, project staffing is completed, and marketing starts. Loan exposure may rise slightly during this phase due to working capital requirements and final payments to contractors and equipment suppliers. Initial sales from project start up enable loan payoff to commerce.ove instances point towards the necessity of having a proper understanding of how the BOT projects operate and how the possible risks arise. Only then can proper risk assessment be done.

\subsection{2) Engineering\& Construction Phase}

The Project Company draws down the majority of the loan to finance construction activity, equipment purchase, and other pre operating costs. This phase can last several years, depending on the size of the project.

\subsection{3) Operation Phase}

Inadequacy of revenue is the most significant risk during this phase, especially from the perspective of debt servicing and acceptable return to project investors. Over a period of time, as the project cash flows stabilize and the exposure of the lenders investors gets reduced, the risk perception also reduces. The most critical risk element that impacts project cost/cash flow under JVs belongs to the financial risk category. This risk factor is "fluctuation of interest rate.

\subsection{4) Financial Risks}

The third most critical risk element that impacts project cost/cash flow under JVs belongs to the financial risk category. This risk factor is "fluctuation of exchange rate." Client's cash flow problems were also identified to have major impact on the execution time of the project. This often involves the client's ability or inability to fund the project through to completion or to make timely payment upon submission of invoices by the contractor.

Financial

Technical

Legal / Cultural

Management

Market

Policy / Political

Social Risk

Environmental Risk

\section{Need for Study}

A BOT project is typically regulated by the government on key issues of the project performances and price of the service. The government can impose some regulations to modify the BOT project to satisfy certain requirements. In the BOT approach, the government grants a private sector the rights to finance, develop, and operate a revenue producing toll road for a defined time period (i.e., concession period) after which the facility is transferred back to the government.

Different pricing strategies of a BOT project are found to serve a wide range of objectives (project performances). From the private sector's viewpoint, the main concern is profit maximization, while under the government's perspective, social welfare maximization for the society is of interest. However, there exists a spatial equity issue in the sense that the changes of the benefits of road users travelling between different origindestination (O-D) pairs may be significantly different when imposing some pricing strategies. This could result in another kind of unfairness to the travelers and become a new obstruction on the implementation of a pricing policy due to public rejection.

There has been growing trends in recent years for government in many countries including India, to place major public investments, particularly, for infrastructure projects, into the private sector. Many of the countries have adopted the BOT approach, so that the private sector has to finance and construct the project facility and then transfer the owner ship to Government after a specified concession period. Therefore BOT scheme is a limited resource project financing technique for implementing infrastructure projects by using private funding. The main objective of this paper is to examine the financial risks in BOT in post construction periodi.e. operation and maintenance period due to change in rate of interest (PLR) and corresponding change in concession period. 


\section{Literature Review}

Laryea and Huges (2011) studied the entire tender process of two leading U.K. construction firms and compared the results. The study revealed that the bidding process was conducted in three stages, and their extent is estimated as deskwork (32\%)] calculations (19\%)] meetings (14\%)] documents (13\%), off days (11\%), conversations $(7 \%)$, correspondence $(3 \%)$ and travel $(1 \%)$, risk allowance $(1-2 \%)$. The findings explain why some assumptions underpinning analytical models may not be sustainable in practice and why what actually happens in practice is important.

Kim and Rein Schmidt (2011) evaluated the effects of contractors risk attitude on the competition in construction. The study finds that risk attitude is a competitive characteristic of contractors and results help in contractor's competitive success.

Ramakrishnan (2010) studied a contractor's perspective to ensure professional project execution. The study revealed that the contractors should follow a systematic approach to get the project, quote reasonable rates and get awarded with suitable conditions.

Gupta and Venkatnarayan (2010) provided an overview of dispute resolution procedures in road projects with reference to the FIDIC form of contract and suggestions for improvement. This paper brings forth the salient features of the entities involved in dispute resolution process and analyzes their status and functioning. The paper concludes with certain suggestions for improvement.

- There exists a communication gap between the involved parties.

- There are risks involved in BOT - Road projects

- Risks depend on quality of work.

- Financial stability is an important factor for risk control.

- Probable risk evaluation depends on individual perception.

\section{Objectives and Data Collection Techniques}

Various past studies has been done on risk analysis . But this study is made specially for analyzing risk in operation period due to fluctuation of PLR. For presentation of this paper, various literatures available online are studied \& various Govt. offices are visited in person for collection of data regarding BOTObjectives of collection of data \& study of specific project which has gone through various risk in its various phases are

To study the role of parties involved in BOT

To study role of road quality in risk

To assess financial risks involved in BOTby studying a specific case of BOT road project

\section{Role of Road Quality in Risk}

Till the projects facility is finally handed over to the govt. at the end of concession period, the entrepreneur shall entirely at his cost carry out repairs and maintain the facility as per specifications for maintenance as specified in section 7 of bid documents. As per this section entrepreneur shall repair and maintain the facility of Roads, Bridges, approaches, C.D. works, other structures till it is finally handed over to the Govt.

The maintenance and repair shall also include repairs of electrical and other installations. He shall take suitable corrective measures for rectification of roughness index $(20000 \mathrm{~mm} / \mathrm{km}-5000$ $\mathrm{mm} / \mathrm{km}$ ) camber, super elevation. If required at the time of handling necessary renewal, strengthening for structural components, furniture and fixtures is also to be done by contractor at his own cost. Due to rough use of road surfaces and damages to structural components, the cost of maintenance may be higher than expected, this is the maintenance Risk.

Road Quality helps both the parties like.

Entrepreneur - If quality work is done at the beginning stage, maintenance cost reduces till the end of concession period.

Government - Due to quality work, risk of maintenance cost of the tolled road is totally diverted towards the contractor and future maintenance gets reduced considerably.

\section{Role of financial stability on project and its effect on risk}

As with most other infrastructure projects, road sector projects are also characterized. By fairly high levels of capital intensity the capital intensity of such projects is however Dependent on a number of variables, which include the nature of the surface (bituminous tar versus concrete), the terrain over which the road traverses, and the number of structures (Bridges. culverts rail over bridges), which need to be constructed. These projects are usually funded with a considerable reliance on external debt, although in most cases liberal grants from the project owners serve to keep leverage moderate Levels. The financing structure is also reviewed for the exposure to interest rate and Refinancing risks, given the limited appetite of the Indian capital markets for fixed interest rate long duration (in excess of IO years) project finance debt. Floating interest rate structure could potentially affect debt servicing, 
particularly during periods of rising interest rates. The capital structure is also reviewed for the repayment structure of the debt- a rear ended maturity profile usually being considered preferable for such projects given that toll revenues usually increase over the first 8-10 years of the concession period. As discussed earlier, the concession agreements for most of these road projects usually provide debt investorswithaccess to a termination payment from the project owner, in the event of default by the projection its contractual commitments. While evaluating the credit risk profile of these projects, view on the ability of the project owner to make such payments and also the sufficiency of these inflows for meeting the debt service commitments of the project must be taken. A key element of the analysis is an assessment of the sufficiency of the revenue stream for meeting operating expenses and debt service obligations. The key sensitivity scenarios that are drawn up include variability in traffic volumes and toll rates, time and cost 'overruns during the construction phase and variability in operations and maintenance expenses post completion. Stress or sensitivity tests are all the more important if it emergesofthe project depends on risk study and bringing them atlowerlevel.

\section{Contractual structure for a toll-road project}

The contractual structure for a toll road project can be diagrammatically constructed by the following chart.

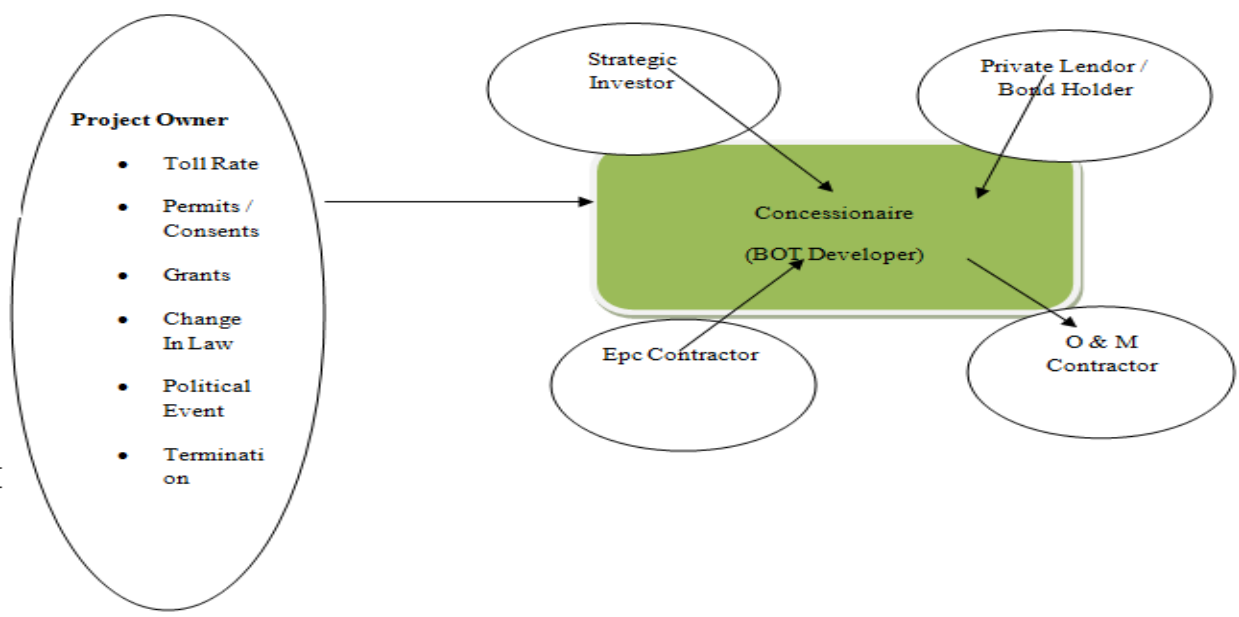

Fig.1- Contractual structure for a toll-road project

As can be seen from the figure given above the concession agreement between the project owner and the concessionaire defines the framework within which such projects operate. Such projects usually implemented within Special Purpose Vehicles (SPVs), which ensure the legal separation of the credit risk profile of these from that of their sponsors. The concession period for such projects usually ranges between 10 and 30 years, and is usually a function expected toll collections along the stretch; as the toll collections impact the time required to service debt and also provide the sponsor reasonable return on their investment.

\subsection{Some of the salient features of a typical Concession Agreement (CA) are:}

The concession agreement entitles the concessionaire to design, engineering, finance, contact, operate and maintain the project facility during concession period as well as to levy and collect toll fees from vehicles for using the project highway or any part thereof.

The concession agreement usually stipulates that the tolls would be levied at rates notified by a government agency and also defines the rates annual escalation in toll rates. The government can also propose exemptions or subsidies for certain vehicle categories. While the traffic risks are to be largely borne by the concessionaire, some concession agreements do make it obligatory for the government to direct vehicle movement in a particular manner or prevent the construction of alternative roads, which to all extent reduces risks.

In the most cases the political risks are assumed by the project owner. Further, some of the concession agreements also have provisions whereby the project ownerundertakes to indemnify the project company from a shortfall in toll collections due to a political, force majeure, through an advance revenue shortfall loans.

The concession agreement usually allocates the risks associated with securing various regulatory approvals, and acquisition of land to the project owner. 


\subsection{Operation Phase}

Inadequacy of revenue is the most significant risk during this phase, especially from the perspective of debt servicing and acceptable return to project investors. Over a period of time, as the project cash flows stabilize and the exposure of the lenders investors gets reduced, the risk perception also reduces.

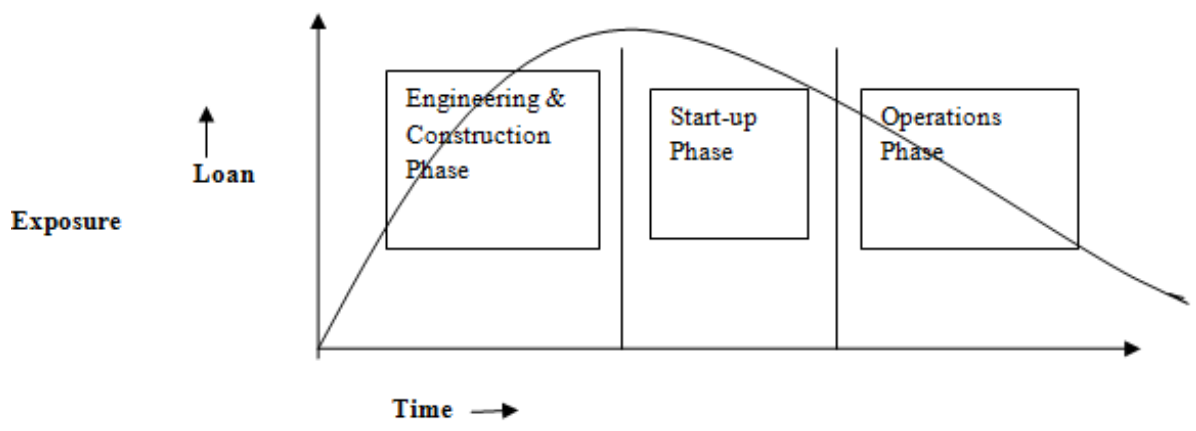

Fig.2 - Project Risk Phases

The above figure reflects upon the risk profile during the various stages of the implementation of an infrastructure project. The level of exposure faced by lenders does not necessarily correspond directly to the risks involved. Specific strategies are adopted at each stage of the project's life either to reduce the likelihood of adverse events or to lay risks off to parties best positioned to manage them. In addition to the risks specific to each phase of the project, there are other risks like politicfal risks and force majeure risks that remain throughout the project period, though the impact may vary based on the project phase.

\section{Risk Analysis for Tolled Road Projects}

Many of the challenges involved in developing and financing road projects are similar to those faced by earlier infrastructure projects. The issues, which assume special importance in the case of toll road projects, however include risks associated with acquisition of long segments of right-of way, cost and time overruns in project implementation due to unforeseen weather conditions and more importantly,the market risks arising out of difficulties in forecasting traffic volumes and their sensitivity to toll rates.

Such projects undergo significant change in their risk profile as they move from the pre-completion to the post- completion stage. While 'permitting risks' and risks associated with timely completion of the project dominate the pre- completion period, the primary risk in the post completion period pertains to the ability of the stretch to attract the necessary amount of traffic, and also for users to pay the requisite amount of tolls.

\section{InstrumentsUsed In Project Financing}

The choice of financial instruments available to borrower varies with the type of project financinginvolved. There are three general categories of capital and loans used in project financing are Equity, Subordinateddebt\&Senior debt.

\section{1) Equity}

The project financing through equity investment is the capital. Equity investors are the last in the priority for repayment lenders look to the equity investments as providing a margin of safety. They have two primary motivations for requiring equity investments. The more burden the debt service puts the cash flow of the project, the greater the lender's risk.Lenders do not want the investors to be in a position to walk away easily from the project. To find the appropriate debt to equity ratio of the project factors are considered as market expectation and risks and guarantees.

\section{2) Subordinated loans}

These senior to equity capital but junior to senior debt and secured debt.Subordinated loans have the advantage of fixed rate long term, insecure and considered as equity.A subordinated loan often used to a project. Sources for subordinated debt include finance companies, capital companies, insurance companies are unsecured.

\section{3) Senior debt}

It contributes the largest portion of the financing. Most borrowings are from commercial banks. It falls into two categories unsecured and secured. Senior debt has an advantage in liquidation over unsecured debt. An insecure loan is debt is backed by general credit of the borrower. In addition to above, there are other sources of 
project finance like multinational agencies, the World Bank, regional development bank, sometimes suppliers and customers are sources of finance.

The above chapters discussed the BOT model, the various risks and their allocation to the parties of the project. The following chapter consist of a case study that illustrate in detail how the model developed in the first part of the paper can be applied to a specific project

10.1 General Data

X. CaseStudy of BOTRoad Project

Construction of major Bridge across River near with By Pass road outside city under BOT

Name of client

Name of the Company

Type of contract

Estimated cost of project

Date of work order

Duration of project

Concession period

Length of service Road

Other side Approach $=930 \mathrm{~m}$.

Bridge length $=148.00 \mathrm{~m}$.

No. of lanes

No. of Toll plaza

Bridge

Over all width of

Superstructure

Type of super structure

Type of foundation

Pier

Nature of foundation start

$15 \mathrm{Omt} / \mathrm{m} 3$

Formation level

Pier cap top level

Well cap top level

Founding level

Executive Engineer, P.W.D.

- XYZ

- B.O.T.

- $\quad 750.00$ lacks.

- 23/03/1999

- $\quad 2$ years

$\quad 16.25$ years.

- $\quad$ onesideApproah - $2592 \mathrm{~m}$.

Observed H. F. L.

$-2$

- $\quad$ Total 4 bays (spans) $37.00 \mathrm{~m}$. with 2 abutments

- $\quad 8.25$ m. (Excluding Foot path)

- $\quad$ Prestressed concrete M-350

- Well foundation for abutments, open foundation for

- $\quad$ Hard Rock with allowable bearing capacity

- $\quad 547.650 \mathrm{~m}$

- $\quad 544.950 \mathrm{~m}$

- $\quad 539.450 / 534.60 \mathrm{~m}$

- $\quad 516.725 / 519.60 \mathrm{~m}$.

- $\quad 543.570 \mathrm{~m}$. (Local enquiry)

10.2 Concession Agreement \& Toll Collection Details

\begin{tabular}{|c|c|c|c|}
\hline $\begin{array}{l}\mathrm{Sr} \\
\mathrm{No}\end{array}$ & Description & Details & Remarks \\
\hline \multicolumn{4}{|c|}{ A. Concession Agreement Details } \\
\hline 1 & Project Cost & Rs. 7.50 Crores & -- \\
\hline \multirow[t]{5}{*}{2} & $\square$ Cost of Repairsand Renewal & Rs. 5.85 Crores & -- \\
\hline & $\square$ Administrative, Establishment \& Toll Collection Charges & Rs. 12.27 Crores & -- \\
\hline & $\square$ Land Acquisition, Utility Services and Miscellaneous Expenses & -- & \begin{tabular}{|l|} 
Not \\
Considered \\
Separately \\
\end{tabular} \\
\hline & $\square$ Inflation Amount & -- & \begin{tabular}{|l|} 
Not \\
Considered \\
Separately
\end{tabular} \\
\hline & $\square$ Cumulative amount of Interest on Bank/Financial Institute Loan & Rs. 21.35 Crores & -- \\
\hline 3 & Project Life Cycle Cost (Sr. No. $1+$ Sr. No. 2$)$ & Rs. 46.97 Crores & -- \\
\hline 4 & Internal Rate of Return (I.R.R.) \% & $10.68 \%$ & -- \\
\hline 5 & Concession Period & 16 Years 3 Months 0 Days & -- \\
\hline 6 & Concessionaire's Equity & Rs. 1.87 Crores & -- \\
\hline 7 & Returns on Equity & Rs. 22.00 Crores & -- \\
\hline 8 & Anticipated Toll Fee & Rs. 68.97 Crores & -- \\
\hline
\end{tabular}




\begin{tabular}{|c|c|c|c|c|}
\hline 9 & \multicolumn{2}{|c|}{ Toll Fee Collection Period (From 25-Oct-2000) } & 14 Years 7 Months 28 Days & -- \\
\hline 10 & \multicolumn{2}{|c|}{ Lender Banks/Financial Institutions } & State Bank of India & -- \\
\hline \multicolumn{5}{|c|}{ B. Toll Fee Collection Details } \\
\hline \multirow[t]{6}{*}{11} & \multicolumn{4}{|l|}{ Toll Fee Collected } \\
\hline & Toll Plaza Name & Toll Fee Collection on Date & Toll Fee Collection & \multirow{5}{*}{-- } \\
\hline & Toll Plaza 1 & 15-Jun-2012 & Rs. 0.01038 Crores & \\
\hline & Toll Plaza 2 & 15-Jun-2012 & Rs. 0.00125 Crores & \\
\hline & Toll Plaza 3 & 15-Jun-2012 & Rs. 0.00004 Crores & \\
\hline & \multicolumn{2}{|l|}{ Total } & Rs.0.01167 Crores & \\
\hline 12 & \multicolumn{2}{|c|}{ Cumulative Toll Fee Collected till Date 15-Jun-2012 } & Rs. 29.37 Crores & \\
\hline
\end{tabular}

Note 1: The above figures (Cost / Period etc.) may change subject to variation in Scope of the Project and or additional works in the Project, and change in Lending Rate / PLR and or as stipulated in the Tender Conditions if any.

Note 2: Contract is based on concession period.

\subsection{V ari ous Risks Faced By Contractor}

The work proposed to be carried shall involve a detail study of the probable risks associated with BOT - Road projects by taking a specific case study. The case study selected for this project is the construction of bypass road (with bridge across river) under BOT. The following work steps shall be carried out as a part of the project.

1) To assess the risks involved in BOT by studying a specific case of aboveBOT - Road Project.

\subsection{1) Technical Risk}

Quoted Amount the contractor should study in detail the estimate, bid documents and as per that he should calculate and check the rates and sign the agreement to avoid the forth coming risk. The site investigation and traffic study may be done by the contractor to check the traffic study donebyP.W.D.department.

In this project there was no provision of extra work of providing $230 \mathrm{~mm}$ diahume pipe for telephone cable. The company has completed the work as per prior permission and laid a 142.75 r.mt. Of 230 mm dia RCC Hume pipe and 174 Nos. of steel insert plates inR.C.C. parapets along with full welding. The company had spent an amount approximately equal to Rs. 48000/-.

In original tender document the item of hume pipes for telephone cable and steel in sert plates at parapet was not included. The risk comes under technical risk i.e. additional work.

The extra work expenditure can be claimed towards PWD and P'WD can get that amount from telephone department then it can be handed over to the entrepreneur.

\subsection{2) Risk due to change in scope of the work}

i) Variation in earth work

As per CEs order issued on 24/11/2009 the ground levels were shown on the basis of surveys conducted on marshy land 5-7 years before the actual construction. During actual execution, earthwork quantities were increased because of the study of work in details and detailed survey was required to be carried out at the time of tender submission and which was not done.

The extra earthwork of $18278.94 \mathrm{~m}^{3}$ with all leads and lifts, with compaction added the cost of construction Rs. 3,976,583.40 as per rate quoted (Rs. 217.65/cm).

The amount added iswithin the scope of the work hence this type of risk can be avoided by detailed survey and study the scope of the work, then only submission of document. Above technical risk cannot be overcome by claims.

ii) Variation in the account of change in depth of foundation of major bridge

As per bore data drawing issued with the tender hard rock level was shown as 2.87 in river bed position. However on ground during soil investigation rock was found at $9.0 \mathrm{~m}$ with standing water 
of $4 / 5 \mathrm{~m}$ above the river bed. Therefore as per opinion of design consultant open foundation was not suitable from execution point of view.

The company had sanctioned the above said work from E E, PWD and completed the work of foundation for Pier No. P1 (9.245 m depth), P2 (12.75 m depth), P3 (8.42 m depth) along with 1.5 in to $10 \mathrm{~m} \mathrm{lift}$, P.CC. M-25 RCC footing and piers and dewatering with placing sand bags around island with service road and extra expenditure was utilized Rs. 47,72,420/-.

The detailed soil investigation was not done by Government department, only two bore holes were taken at the ends of the river bed and the data was utilized for all other piers location. The drawings submitted by Government department shows this as mistake in drawing. Hence the scope of work was changed for pile no. 01, 02, 03, as location of hard rock at $9.24 \mathrm{~m}$, $12.75 \mathrm{~m}, 8.42 \mathrm{~m}$ respectively.

Hence additional cost of foundation must be given to entrepreneur by additional concession period.

iii) Widening of 4 Nos. of C. D. works

As per contract document the 4 Nos. of C.D. works are shown with width $7.5 \mathrm{~m}$. Further it was ordered by E.E. (PWD) to contractor to widen the width of 10 in (in-in dimension).

The construction company had taken the joint measurements and completed the extra items as per order form E.E. (PWD) and additional expenditure of Rs. 2,36,109.00 was spent for such work including dismantling stone masonry, excavation, rubble filling, R.CC hume pipe $900 \mathrm{~mm}$. providing new U.C.R. masonry in CM 1:6 and dry stone pitching etc. complete.

As per rule for $7 \mathrm{~m}$ road width C.D. work should be of $10 \mathrm{~m}$ width (as per todays rule it is 1.2 in to $7 \mathrm{~m}$ road width)

Drawing details are wrong, which shows only $8.25 \mathrm{~m}$. Hence due to change in scope of the work additional expenditure of widening may be compensated by adjusting concession period.

10.3.3) Improvement for existing old Road

By EE PWD under his site note issued a variation order to improve the old road to match with Road Top level (RTL) for the proposed road for smooth plying of vehicles. With due sanction and permission and written acceptance the extra work was carried out by xyz as per clause 3.6 of C.A. @ noninvolvement in material change in scope or nature of project.

The new work relating to earthwork for $9 \mathrm{~m}$ embankment, W. B. M. (150 mm thick) BBM $(75 \mathrm{~mm}$ thick) tack coat and 25 in semi-dense bitumen carpet with $6 \%$ asphalt was carried out by spending extra cost R.s. $1,46.983 /-$.

10.3.4) Escalation for Bitumen

As per clause 4.6.7 of concession agreement provisions for escalation to be paid to the contractor for Bitumen consumed in the work as per 4.6.6.3. The entrepreneur should keep the record of bitumen consumed and additional amount payable to him is calculated as per equation.

$\mathrm{Vb}=\mathrm{R}(\mathrm{Bl}-\mathrm{BO})$

$\mathrm{Vb}=$ Additional amount payable to contractor

$\mathrm{R}=$ Total amount of bitumen consumed during concession period.

B1 - The average official retail price of bitumen at IOC Mumbai for the $15^{\text {th }}$ day of middle calendar month of the month under consideration.

BO - The average official retail price of bitumen at IOC dept at Mumbai on the day, 30 days prior to date of opening of bids.

By noting the amount of bitumen consumed the contractor had claimed an amount Rs. 5, 44,040/against the bitumen escalation. As per clause in Tender document above amount is payable to entrepreneur or adjust the concession period.

10.3.5) Force majeure Risk (Act of god)

Compensation towards transportation strike

From $14 / 04 / 2003$ to $24 / 04 / 2003$

And 21/08/2004 - 29/08/2004

All India transporters strike was stared on 14/04/2003 and 21/08/2004 due to which the toll collection was drastically reduced for 11 days and 9 days respectively.

As per relevant contract provision clause 4.4.19 reads as "If at any time during the execution/completion of the project the entrepreneur is not able to proceed with constructing/completion of the project beyond a period of one month due to any reason beyond his control such as fire, earth quake, floods, 
storm, or any other such calamity, riots, civil commotion the Govt. shall compensate the entrepreneur for such losses in a manner and form as may be decided by the govt. If also the entrepreneur is not able for a period even less than a month to collect any toll or if the toll collection is drastically reduced below $20 \%$ of "normal collection" due to any reasons beyond his control such strikes, riots, civil commotion etc, the Govt. shall compensate him for such deficit/short fall in toll collection along with simple interest equivalent to prime lending rate of SBI prevailing at the time. Amount of such deficit/shortfall along with the interest thereon shall be paid by the Govt. to the entrepreneur in lump sum within 6 months after the demand of such claims. The Govt. however shall have the option of extending the concession period, in lieu of such payment. If there is any short fall in toll collection due to wrong estimation of traffic by the entrepreneur, or if he fails to collect toll for any other reason, the Govt. shall not compensate the deficit loss or short fall.

The risk of toll loss for $(11+9)$ days is shown as per table

\begin{tabular}{|l|l|l|}
\hline $\begin{array}{l}\text { No. of days on which toll was } \\
\text { reduced }(20 \%) \text { below normal toll } \\
\text { collection }\end{array}$ & $\begin{array}{l}\text { Normal toll collection } \\
\text { Rs. }\end{array}$ & $\begin{array}{l}\text { Total loss of toll } \\
\text { Rs. }\end{array}$ \\
\hline 11 days (April) & $73,671 /-$ & $6,64,900 /-$ \\
\hline 09 days (August) & $90,984 /-$ & $7,06,904 /-$ \\
\hline
\end{tabular}

The monthly pass for toll was already collected it should be included in calculations. Toll collected prior to this claim shows that the amount is satisfactory and it is a force majeure risk which may be beared by entrepreneur. 'Normal toll collection means average forthright toll collection prior to the strike. It shows some difference between PWD calculations and claimed figures

\subsection{6)Non-shifting of electric poles and HT. lines}

After request about removal of trees and electric poles at the junction of proposed road and existing road, the contractor was unable to transport huge precast girders for bridge erection. Entrepreneur also approached S.E. for removal of poles and electric lines due to delay in removal of these schedule of project was beyond the planned program and precious period was lost. As per the clause of acquisition of land is the responsibility of govt.

\subsection{7) Extra compensation on account of conducting pile load test}

Due to variation in strata $(2.5 \mathrm{~m}$ in drawing and average $7 \mathrm{~m}$ by bore test) the open well foundation was not suitable. As per clause 3.6 - 3.61, 3:6:2 the variation means on order issued by the engineer requiring a variation change, modification and alteration or any change in design criteria, extra cost of Rs. 1,02,925/- was spent for pile load test.

\subsection{8) Force majeure Risk}

Compensation towards loss of toll caused by flood between 01.08.05 - 08.08.05 During July-August 2005 there had been heavy rain reported over Maharashtra and particular heavy rains in Krishna River basin. This result into unexpected floods and drop in traffic passing over the road. The entrepreneur had reported about reduction in toll collection below $80 \%$ of normal collection. Toll station was under water Newspapers were the proof of the same.

The relevant contract provision by clause No. 4.4.19 if during execution completion of the project the entrepreneur is not able for a period even less than a month to collect any toll or if the toll collection is drastically reduced below $20 \%$ of normal toll collection due to any reason beyond his control strike, riots, commotion, the Govt. shall compensate him for such deficit/short fall in toll collection along with simple interest equivalent to prime lending rate of SB1 prevailing at that time. Amount of such deficit/shortfall should be paid within 60 days of claim or Govt. shall have the option of extending the concession period. Total economical loss by the entrepreneur for this was Rs. 7, 38,208/- along with interest as per SBI, otherwise extension towards concession period. Newspaper data's were not found suitable for the facts and calculation of loss should be done on fortnight period to flood event.

\subsection{9) Risk of Arbitration fees"}

Cost of Arbitration (Legal Expenses)

If the extra expenses towards additional cost, change in Prime Lending Rates, design changes, delays, lapses due to strike or floods are not paid by the govt. or delayed, the 
entrepreneur may take the help of arbitrator. Cost of arbitrator is also increased the economical burden on contractor. It is a risk coming under legal risk.

The $50 \%$ of the arbitration charges should be shared by the Government.

\subsubsection{0) Traffic Risk}

Calculation of traffic and prediction of traffic volume

Under the clause 4.7.1, 4.7.2 about stipulations the entrepreneur shall carry out his own traffic volume study and future growth. Only traffic intensity data observed during last five years is made available to the entrepreneur if asked in writing. The govt. shall not accept any responsibility on the account of loss for any change in traffic plying.

Percentage increase in traffic is taken $10 \%$ of average of traffic observed to the date of Origin and Destination survey. Projected traffic of any area depends on industrial increase (development) of the area. If by any reason industrial development of the area drastically reduces by considerable amount, the toll collection reduces, automatically economic loss of entrepreneur takes place; which comes under traffic risk category. In my case study it is satisfactory.

\subsubsection{1) Risk due to future traffic routes/facilities}

By stipulation clause 4.7.3 Govt. reserves the right on the existing or future traffic routes or facilities to be provided by the government and also no restriction shall be imposed by the entrepreneur on the traffic plying on this road-during the construction unless approved by S.E.

If by constructing future traffic route the road users on existing (constructed) B.O.T. road may reduce and toll collection may be reduced; during the concession period. This is also on type of traffic volume reduction risk.

By clause 4.7.29 Govt. reserves the right to carry out or permit to carry out any other facilities near any or all sections of project, at any time during the period of construction, operate or maintenance period of the project. The entrepreneur shall permit access to such facility without any claim for damages, compensation, time delay etc. The entrepreneur has the risk of extra expenses of damages, compensation or delay.

By clause 4.7.22 the Govt. reserves the rights to reduce the toll rates in consultation with entrepreneur at any time once during concession period up to $10 \%$ of prevailing toll rates. Remaining concession period will be adjusted based on cash flow submitted by entrepreneur. This leads to financial loss of contractor is one type of risk.

4.7.17 clause shows that if at any point of time, it is decided to setup octroi station by the concerned local authority along the road, the required access for the same shall be allowed by the entrepreneur.

\subsubsection{2) Prime lending Rate Risk}

As per clause 4.7.11 in case of change in lending interest rates by $R B I$ the concession period in the contract shall be re-worked with suitable adjustment for changed rates based on cash flow statement/projected statement of loan and repayment, this is one type of risk.

Govt. Banks reserves some amount with 3-4\% extra rate than general loan rates for such infrastructure projects, the rate of such loan is called as Prime Lending Rate (PLR).

Govt. alters the concession period for every year for PL Rate change but PLR of bank changes at approximately 3 months.

\subsubsection{3) Changes in rules/laws}

As per clause 4.4.24 The entrepreneur shall at all times during concession period comply fully with all existing laws regulations bye-laws, including all statutory amendments and reenactment of state Govt. or Govt. of India and other local authority and any other enactment, notifications and acts that may be passed in future and schemes made under same act and health or sanitary arrangements for workmen. For example - As per old rules (before 2005) $10 \mathrm{~km}$ distance from toll center are treated as nearby vicinity people, those are not required to pay the toll. Now after year 2005 the rule is changed for new projects of $15 \mathrm{~km}$. distance is called as nearby vicinity and are not required to pay the toll. By new rules, rounding up of the toll rate is done using advanced systems for toll collection centers regarding new boards receipt systems. 


\subsubsection{4) Bypass or Service Road}

The Govt. has kept right with them to develop any bypass road at any time during the concession period. By this the toll collection of existing road may reduce to considerable amount. It is risk towards entrepreneur as reduction of toll as expected or calculated.

\section{4) Cash flows}

After identifying the risks involved in a BOT project, it is very essential to look at the techniques for analyzing project cash flows. This is a major function in the risk management process.

In the previous sections, it was mentioned that deferent risks relate to different stages in a BOT scheme, and that any BOT infrastructure project can be viewed as two projects; a higher risk construction project and a lower risk utility project. Following is a description of the risk pattern that explains this distinction. After commencement of the construction work, the risk begins to increase as money is used to pay for material, labor, and equipment. Interest charges on loans start accumulating. Force majeure risks also increase during the construction and development phase. All these risks reach their peak value in the early operational years of the projects because of the pressure due to maximum debt service when the highest interest burden occurs. When the operation phase starts, the revenues are collected from toll fees, and debts are paid. This pattern of risk distribution should be appreciated by all parties involved in the project. Investors should expect divi-dent payment only after risks have leveled off. Lender should expect repayment according to progressive schedule. The government should also consider this risk pattern when structuring the concessionaire's obligation (Welker 1995)

In general, reducing the risk to one party consists of passing this risk to other parties. The role of the project sponsors is to evaluate the risk and allocate them to the parties best able to assume them. The allocation of risk to parties like contractor will bring additional cost to the project. Also, converge of risks by insurance companies' increases the cost of the project.

As per clause 4.7.11 in case of change in lending interest rates by RBI the concession period in the contract shall be re-worked with suitable adjustment for changed rates based on cash flow statement/projected statement of loan and repayment, this is one type of risk.

Govt. Banks reserves some amount with 3-4\% extra rate than general loan rates for such infrastructure projects, the rate of such loan is called as Prime Lending Rate (PLR).

Govt. alters the concession period for every year for PL Rate change but PLR of bank changes at approximately 3 months

Following chart shows the typical case study of the construction of Major Bridge through B.O.T.

\subsection{1)Cash flow as per Toll Rates \& AcceptedTender Form}

Four numbers ofCash flows are presented to show variation in concession period due to change in prime lending rate.

1) Cash flow no. 1 shows the original cash flow

2) Cash flow no. 2 shows the Cash flow along with the accepted tender

3) Cash flow no.3shows reduction in concession period due to change in prime lending rate due to change in

PLR concession period is drastically reduced

4) Cash flow no. 4 shows change in concession period due to consideration of claims amount in cash flow

\subsection{2) Tables}

Two tables showing REPO rates given by RBI from the period 20-10-2008...to17-04-2012 \& corresponding calculations for the rate of interest.

1) Table no.1 shows REPO rates given by RBI from the period 20-10-2008to 17-04-2012

2) Table no. 2 shows corresponding calculations for the rate of interest from the REPO rate for table no. 1

Name ofWork: Const. of Major Bridge across River and Bye pass outside City under B.O.T.

\section{Cash FlowNo.1: Original Cash Flow}

\begin{tabular}{|c|c|c|c|c|c|c|c|c|c|c|c|c|}
\hline \multicolumn{2}{|c|}{ Rate of Interest } & \multicolumn{6}{|c|}{$23 \%$} & \multicolumn{5}{|c|}{ Negotiated Tendered Cash flow } \\
\hline \multicolumn{2}{|c|}{ Period } & $\begin{array}{c}\mathbf{Y} \\
\mathbf{e a} \\
\mathbf{r}\end{array}$ & & & \multicolumn{5}{|c|}{ Details of Expenditure } & \multicolumn{3}{|c|}{ Cash flow details } \\
\hline From & To & & Toll & $\begin{array}{l}\text { Adve } \\
\text { rtise } \\
\text { ment }\end{array}$ & $\begin{array}{c}\text { Cons } \\
\text { t. } \\
\text { Cost }\end{array}$ & $\begin{array}{c}\text { Interes } \\
\mathrm{t}\end{array}$ & $\begin{array}{c}\mathrm{M} \& \\
\mathrm{R}\end{array}$ & $\begin{array}{c}\text { Opera } \\
\text { ting } \\
\text { Cost }\end{array}$ & $\begin{array}{l}\text { Total } \\
\text { expen } \\
\text { diture }\end{array}$ & $\begin{array}{c}\text { Net } \\
\text { Yearl } \\
\text { y } \\
\text { cash } \\
\text { flow }\end{array}$ & $\begin{array}{l}\text { Outstan } \\
\text { ding } \\
\text { amount }\end{array}$ & IRR \\
\hline
\end{tabular}


Risk Assessment of BOT Road Projects

\begin{tabular}{|c|c|c|c|c|c|c|c|c|c|c|c|c|}
\hline 1 & 2 & 3 & 4 & 5 & 6 & 7 & 8 & 9 & 10 & 11 & & 13 \\
\hline $\begin{array}{c}23-03- \\
99 \\
\end{array}$ & $\begin{array}{c}22-03- \\
00\end{array}$ & 1 & 0.00 & 0.00 & $\begin{array}{c}375 . \\
00\end{array}$ & 43.13 & 0.00 & 0.00 & $\begin{array}{c}418.1 \\
3 \\
\end{array}$ & $\begin{array}{c}- \\
418 . \\
13 \\
\end{array}$ & 418.13 & $\begin{array}{l}\text { \#NU } \\
\mathrm{M} !\end{array}$ \\
\hline $\begin{array}{c}23-03- \\
00\end{array}$ & $\begin{array}{c}22-03- \\
01\end{array}$ & 2 & 0.00 & 0.00 & $\begin{array}{c}375 . \\
00\end{array}$ & 139.29 & 0.00 & 0.00 & $\begin{array}{c}514.2 \\
9\end{array}$ & $\begin{array}{c}- \\
514 . \\
29\end{array}$ & 932.42 & $\begin{array}{l}\text { \#NU } \\
\mathrm{M} !\end{array}$ \\
\hline $\begin{array}{c}23-03- \\
01\end{array}$ & $\begin{array}{c}22-03- \\
02\end{array}$ & 3 & $\begin{array}{c}243.9 \\
2\end{array}$ & 0.00 & 0.00 & 214.46 & 11.25 & 42.00 & $\begin{array}{c}267.7 \\
1 \\
\end{array}$ & $\begin{array}{c}23.7 \\
9 \\
\end{array}$ & 956.21 & $\begin{array}{l}\text { \#NU } \\
\mathrm{M} !\end{array}$ \\
\hline $\begin{array}{c}23-03- \\
02\end{array}$ & $\begin{array}{c}22-03- \\
03\end{array}$ & 4 & $\begin{array}{c}256.0 \\
8 \\
\end{array}$ & 0.00 & 0.00 & 219.93 & 12.38 & 46.20 & $\begin{array}{c}278.5 \\
0\end{array}$ & $\begin{array}{c}- \\
22.4 \\
2\end{array}$ & 978.63 & $\begin{array}{l}\text { \#NU } \\
\mathrm{M} !\end{array}$ \\
\hline $\begin{array}{c}23-03- \\
03\end{array}$ & $\begin{array}{c}22-03- \\
04\end{array}$ & 5 & 268.9 & 0.00 & 0.00 & 225.08 & 13.61 & 50.82 & $\begin{array}{c}289.5 \\
2\end{array}$ & $\begin{array}{c}- \\
20.6 \\
2\end{array}$ & 999.24 & $\begin{array}{l}\text { \#NU } \\
\mathrm{M} !\end{array}$ \\
\hline $\begin{array}{c}23-03- \\
04\end{array}$ & $\begin{array}{c}22-03- \\
05\end{array}$ & 6 & $\begin{array}{c}332.0 \\
9\end{array}$ & 0.00 & 0.00 & 229.83 & 14.97 & 55.90 & $\begin{array}{c}300.7 \\
0 \\
\end{array}$ & $\begin{array}{c}31.3 \\
9 \\
\end{array}$ & 967.86 & $\begin{array}{l}\text { \#NU } \\
\mathrm{M} !\end{array}$ \\
\hline $\begin{array}{c}23-03- \\
05 \\
\end{array}$ & $\begin{array}{c}22-03- \\
06\end{array}$ & 7 & $\begin{array}{c}348.6 \\
9 \\
\end{array}$ & 0.00 & 0.00 & 222.61 & 66.47 & 61.49 & $\begin{array}{c}350.5 \\
7 \\
\end{array}$ & -1.88 & 969.74 & $\begin{array}{l}\text { \#NU } \\
\mathrm{M!}\end{array}$ \\
\hline $\begin{array}{c}23-03- \\
06\end{array}$ & $\begin{array}{c}22-03- \\
07\end{array}$ & 8 & $\begin{array}{c}366.1 \\
3\end{array}$ & 0.00 & 0.00 & 223.04 & 18.12 & 67.64 & $\begin{array}{c}308.8 \\
0\end{array}$ & $\begin{array}{c}57.3 \\
3 \\
\end{array}$ & 912.40 & $-35 \%$ \\
\hline $\begin{array}{c}23-03- \\
07\end{array}$ & $\begin{array}{c}22-03- \\
08\end{array}$ & 9 & $\begin{array}{c}442.0 \\
4\end{array}$ & 0.00 & 0.00 & 209.85 & 19.93 & 74.41 & $\begin{array}{c}304.1 \\
9 \\
\end{array}$ & $\begin{array}{c}137 . \\
85\end{array}$ & 77 & $-20 \%$ \\
\hline $\begin{array}{c}23-03- \\
08 \\
\end{array}$ & $\begin{array}{c}22-03- \\
09 \\
\end{array}$ & 10 & $\begin{array}{c}664.1 \\
4 \\
\end{array}$ & 0.00 & 0.00 & 178.15 & 21.92 & 81.85 & $\begin{array}{c}281.9 \\
2 \\
\end{array}$ & $\begin{array}{c}182 . \\
22 \\
\end{array}$ & 592.33 & $-11 \%$ \\
\hline $\begin{array}{c}23-03- \\
09\end{array}$ & $\begin{array}{c}22-03- \\
10\end{array}$ & 11 & $\begin{array}{c}487.3 \\
5\end{array}$ & 0.00 & 0.00 & 136.24 & 24.12 & 90.03 & $\begin{array}{c}250.3 \\
8 \\
\end{array}$ & $\begin{array}{c}236 . \\
97\end{array}$ & 355.36 & $\begin{array}{c}- \\
5.28 \%\end{array}$ \\
\hline $\begin{array}{c}23-03- \\
10 \\
\end{array}$ & $\begin{array}{c}22-03- \\
11 \\
\end{array}$ & 12 & $\begin{array}{c}593.4 \\
3 \\
\end{array}$ & 0.00 & 0.00 & 81.73 & 106.53 & 99.03 & $\begin{array}{c}287.2 \\
9 \\
\end{array}$ & $\begin{array}{c}306 . \\
14 \\
\end{array}$ & 49.23 & $\begin{array}{c}- \\
0.57 \% \\
\end{array}$ \\
\hline $\begin{array}{c}23-03- \\
11 \\
\end{array}$ & $\begin{array}{c}22-03- \\
12 \\
\end{array}$ & 13 & $\begin{array}{c}623.1 \\
1 \\
\end{array}$ & 0.00 & 0.00 & 11.32 & 29.18 & $\begin{array}{c}108.9 \\
4 \\
\end{array}$ & $\begin{array}{c}149.4 \\
4 \\
\end{array}$ & $\begin{array}{c}473 . \\
67 \\
\end{array}$ & -424.44 & $3.76 \%$ \\
\hline $\begin{array}{c}23-03- \\
12 \\
\end{array}$ & $\begin{array}{c}22-03- \\
13 \\
\end{array}$ & 14 & $\begin{array}{c}654.2 \\
6 \\
\end{array}$ & 0.00 & 0.00 & 0.00 & 32.10 & $\begin{array}{c}119.8 \\
3 \\
\end{array}$ & $\begin{array}{c}151.9 \\
3 \\
\end{array}$ & $\begin{array}{c}502 . \\
33 \\
\end{array}$ & -926.78 & $6.63 \%$ \\
\hline $\begin{array}{c}23-03- \\
13 \\
\end{array}$ & $\begin{array}{c}22-03- \\
14\end{array}$ & 15 & $\begin{array}{c}781.5 \\
7 \\
\end{array}$ & 0.00 & 0.00 & 0.00 & 35.31 & $\begin{array}{c}131.8 \\
1 \\
\end{array}$ & $\begin{array}{c}167.1 \\
2 \\
\end{array}$ & $\begin{array}{c}614 . \\
45\end{array}$ & $\begin{array}{c}- \\
1541.22 \\
\end{array}$ & $8.96 \%$ \\
\hline $\begin{array}{c}23-03- \\
14 \\
\end{array}$ & $\begin{array}{c}22-03- \\
15 \\
\end{array}$ & 16 & $\begin{array}{c}820.6 \\
5 \\
\end{array}$ & 0.00 & 0.00 & 0.00 & 38.84 & $\begin{array}{c}145.0 \\
0 \\
\end{array}$ & $\begin{array}{c}183.8 \\
3 \\
\end{array}$ & $\begin{array}{c}636 . \\
82 \\
\end{array}$ & $\begin{array}{c}- \\
2178.04 \\
\end{array}$ & $\begin{array}{c}10.64 \\
\%\end{array}$ \\
\hline $\begin{array}{c}23-03- \\
15 \\
\end{array}$ & $\begin{array}{c}22-06- \\
15 \\
\end{array}$ & $\begin{array}{c}16 \\
.2 \\
5 \\
\end{array}$ & $\begin{array}{c}215.4 \\
2 \\
\end{array}$ & 0.00 & 0.00 & 0.00 & 140.68 & 51.93 & $\begin{array}{c}192.6 \\
1 \\
\end{array}$ & $\begin{array}{c}22.8 \\
1 \\
\end{array}$ & $\begin{array}{c}- \\
2200.85 \\
\end{array}$ & $\begin{array}{c}10.68 \\
\% \\
\end{array}$ \\
\hline & & & $\begin{array}{c}6897 . \\
78\end{array}$ & & $\begin{array}{c}750 . \\
00\end{array}$ & $\begin{array}{c}2134.6 \\
5 \\
\end{array}$ & 585.40 & $\begin{array}{c}1226 . \\
88\end{array}$ & $\begin{array}{c}4696 . \\
93\end{array}$ & & & \\
\hline
\end{tabular}

\begin{tabular}{|l|l|l|}
\hline Particulars & As per submitted cash flow(16.75th Years) & $\begin{array}{l}\text { Revised Cash flow for sanctioned } \\
\text { period(16.25th Years) }\end{array}$ \\
\hline Toll Amount & 646.00 lakhs & $646.00 / 3.00==215.42$ lakhs \\
\hline M\&R Cost & {$[(38.84 \times 1.10) \times 0.75]+130.00=162.04 \mathrm{~L}$} & $\begin{array}{l}{[(38.84 \times 1.10) \times 0.25]+} \\
130.00=140.68 \mathrm{~L}\end{array}$ \\
\hline Operating Cost & 207.71 lakhs & $207.71 / 4.00==51.93$ lakhs \\
\hline
\end{tabular}

Cash Flow No.2: Cash Flow along with the accepted tender.

Rate of Interest $\quad 23 \% \quad$ Submitted along with tender

\begin{tabular}{|c|c|c|c|c|c|c|c|c|c|c|c|c|}
\hline \multicolumn{2}{|c|}{ Period } & $\begin{array}{l}Y \\
\text { ea } \\
r\end{array}$ & $\begin{array}{c}\text { Det } \\
\text { In }\end{array}$ & & \multicolumn{5}{|c|}{ Details of Expenditure } & \multicolumn{3}{|c|}{ Cash flow details } \\
\hline From & To & & Toll & $\begin{array}{l}\text { Ad } \\
\text { v. }\end{array}$ & $\begin{array}{l}\text { Const. } \\
\text { Cost }\end{array}$ & Interest & $\begin{array}{l}M \& \\
R\end{array}$ & $\begin{array}{l}\text { Operati } \\
\text { ng } \\
\text { Cost }\end{array}$ & $\begin{array}{l}\text { Total } \\
\text { expen } \\
\text { diture }\end{array}$ & $\begin{array}{l}\text { Net } \\
\text { Yrly.c } \\
\text { ash } \\
\text { flow }\end{array}$ & $\begin{array}{l}\text { Outsta } \\
\text { nding } \\
\text { amount }\end{array}$ & I R R \\
\hline
\end{tabular}




\begin{tabular}{|c|c|c|c|c|c|c|c|c|c|c|c|c|}
\hline 1 & 2 & 3 & 4 & 5 & 6 & 7 & 8 & 9 & 10 & 11 & & 13 \\
\hline $\begin{array}{l}23-03- \\
99\end{array}$ & $\begin{array}{l}22-03- \\
00\end{array}$ & 1 & 0.00 & $\begin{array}{r}0.0 \\
0\end{array}$ & $\begin{array}{r}375.0 \\
0\end{array}$ & 43.13 & 0.00 & 0.00 & 418.13 & $\begin{array}{r}418.1 \\
3\end{array}$ & 418.13 & $\begin{array}{l}\text { \#NU } \\
\mathrm{M} !\end{array}$ \\
\hline $\begin{array}{l}\text { 23-03- } \\
00\end{array}$ & $\begin{array}{l}22-03- \\
01\end{array}$ & 2 & 0.00 & $\begin{array}{r}0.0 \\
0 \\
\end{array}$ & $\begin{array}{r}375.0 \\
0 \\
\end{array}$ & 139.29 & 0.00 & 0.00 & 514.29 & $\begin{array}{r}- \\
514.2 \\
9\end{array}$ & 932.42 & $\begin{array}{l}\text { \#NU } \\
\mathrm{M} !\end{array}$ \\
\hline $\begin{array}{l}\text { 23-03- } \\
01\end{array}$ & $\begin{array}{l}22-03- \\
02\end{array}$ & 3 & 243.92 & $\begin{array}{r}0.0 \\
0\end{array}$ & 0.00 & 214.46 & 11.25 & 42.00 & 267.71 & $\begin{array}{r}- \\
23.79\end{array}$ & 956.21 & $\begin{array}{l}\text { \#NU } \\
\mathrm{M} !\end{array}$ \\
\hline $\begin{array}{l}\text { 23-03- } \\
02\end{array}$ & $\begin{array}{l}22-03- \\
03\end{array}$ & 4 & 256.08 & $\begin{array}{r}0.0 \\
0\end{array}$ & 0.00 & 219.93 & 12.38 & 46.20 & 278.50 & $22.42^{-}$ & 978.63 & $\begin{array}{l}\text { \#NU } \\
\mathrm{M} !\end{array}$ \\
\hline $\begin{array}{l}\text { 23-03- } \\
03\end{array}$ & $\begin{array}{l}22-03- \\
04\end{array}$ & 5 & 268.9 & $\begin{array}{r}0.0 \\
0\end{array}$ & 0.00 & 225.08 & 13.61 & 50.82 & 289.52 & 20.62 & 999.24 & $\begin{array}{l}\text { \#NU } \\
\mathrm{M} !\end{array}$ \\
\hline $\begin{array}{l}\text { 23-03- } \\
04\end{array}$ & $\begin{array}{l}22-03- \\
05\end{array}$ & 6 & 332.09 & $\begin{array}{r}0.0 \\
0\end{array}$ & 0.00 & 229.83 & 14.97 & 55.90 & 300.70 & 31.39 & 967.86 & $\begin{array}{l}\text { \#NU } \\
\text { M! }\end{array}$ \\
\hline $\begin{array}{l}\text { 23-03- } \\
05\end{array}$ & $\begin{array}{l}22-03- \\
06\end{array}$ & 7 & 348.69 & $\begin{array}{r}0.0 \\
0\end{array}$ & 0.00 & 222.61 & 66.47 & 61.49 & 350.57 & -1.88 & 969.74 & $\begin{array}{l}\text { \#NU } \\
\mathrm{M} !\end{array}$ \\
\hline $\begin{array}{l}\text { 23-03- } \\
06\end{array}$ & $\begin{array}{l}22-03- \\
07 \\
\end{array}$ & 8 & 366.13 & $\begin{array}{r}0.0 \\
0 \\
\end{array}$ & 0.00 & 223.04 & 18.12 & 67.64 & 308.80 & 57.33 & 912.40 & $\begin{array}{l}\text { \#NU } \\
\mathrm{M} !\end{array}$ \\
\hline $\begin{array}{l}\text { 23-03- } \\
07\end{array}$ & $\begin{array}{l}22-03- \\
08\end{array}$ & 9 & 442.04 & $\begin{array}{r}0.0 \\
0\end{array}$ & 0.00 & 209.85 & 19.93 & 74.41 & 304.19 & $\begin{array}{r}137.8 \\
5\end{array}$ & 774.55 & $\begin{array}{c}\text { \#DIV/ } \\
0 !\end{array}$ \\
\hline $\begin{array}{l}23-03- \\
08\end{array}$ & $\begin{array}{l}22-03- \\
09\end{array}$ & 10 & 464.14 & $\begin{array}{r}0.0 \\
0\end{array}$ & 0.00 & 178.15 & 21.92 & 81.85 & 281.92 & $\begin{array}{r}182.2 \\
2\end{array}$ & 592.33 & $\begin{array}{l}\text { \#NU } \\
\mathrm{M} !\end{array}$ \\
\hline $\begin{array}{l}23-03- \\
09\end{array}$ & $\begin{array}{l}22-03- \\
10\end{array}$ & 11 & 487.35 & $\begin{array}{r}0.0 \\
0 \\
\end{array}$ & 0.00 & 136.24 & 24.12 & 90.03 & 250.38 & $\begin{array}{r}236.9 \\
7 \\
\end{array}$ & 355.36 & $5.28 \%$ \\
\hline $\begin{array}{l}23-03- \\
10\end{array}$ & $\begin{array}{l}22-03- \\
11\end{array}$ & 12 & 593.43 & $\begin{array}{r}0.0 \\
0 \\
\end{array}$ & 0.00 & 81.73 & $\begin{array}{r}106.5 \\
3 \\
\end{array}$ & 99.03 & 287.29 & $\begin{array}{r}306.1 \\
4 \\
\end{array}$ & 49.23 & $0.57 \%$ \\
\hline $\begin{array}{l}23-03- \\
11\end{array}$ & $\begin{array}{l}22-03- \\
12\end{array}$ & 13 & 623.11 & $\begin{array}{r}0.0 \\
0 \\
\end{array}$ & 0.00 & 11.32 & 29.18 & 108.94 & 149.44 & $\begin{array}{r}473.6 \\
7 \\
\end{array}$ & -424.44 & $3.76 \%$ \\
\hline $\begin{array}{l}23-03- \\
12\end{array}$ & $\begin{array}{l}22-03- \\
13\end{array}$ & 14 & 654.26 & $\begin{array}{r}0.0 \\
0 \\
\end{array}$ & 0.00 & 0.00 & 32.10 & 119.83 & 151.93 & $\begin{array}{r}502.3 \\
3 \\
\end{array}$ & -926.78 & $6.63 \%$ \\
\hline $\begin{array}{l}23-03- \\
13\end{array}$ & $\begin{array}{l}22-03- \\
14\end{array}$ & 15 & 781.57 & $\begin{array}{r}0.0 \\
0 \\
\end{array}$ & 0.00 & 0.00 & 35.31 & 131.81 & 167.12 & $\begin{array}{r}614.4 \\
5 \\
\end{array}$ & $\begin{array}{r}- \\
1541.2 \\
2 \\
\end{array}$ & $8.96 \%$ \\
\hline $\begin{array}{l}23-03- \\
14\end{array}$ & $\begin{array}{l}22-03- \\
15\end{array}$ & 16 & 820.65 & $\begin{array}{r}0.0 \\
0 \\
\end{array}$ & 0.00 & 0.00 & 38.84 & 145.00 & 183.83 & $\begin{array}{r}636.8 \\
2 \\
\end{array}$ & $\begin{array}{r}- \\
2178.0 \\
4 \\
\end{array}$ & $\begin{array}{r}10.64 \\
\% \\
\end{array}$ \\
\hline \multirow[t]{2}{*}{$\begin{array}{l}23-03- \\
15 \\
\end{array}$} & $\begin{array}{r}22-12- \\
15 \\
\end{array}$ & $\begin{array}{r}16 \\
.7 \\
5 \\
\end{array}$ & 646.26 & $\begin{array}{r}0.0 \\
0 \\
\end{array}$ & 0.00 & 0.00 & $\begin{array}{r}162.0 \\
4 \\
\end{array}$ & 207.71 & 369.75 & $\begin{array}{r}276.5 \\
1 \\
\end{array}$ & $\begin{array}{r}- \\
2454.5 \\
5\end{array}$ & $\begin{array}{r}11.19 \\
\% \\
\end{array}$ \\
\hline & & & $\begin{array}{r}7328.6 \\
2\end{array}$ & & $\begin{array}{r}750.0 \\
0\end{array}$ & $\begin{array}{r}2134.6 \\
5\end{array}$ & $\begin{array}{r}606.7 \\
6\end{array}$ & $\begin{array}{r}1382.6 \\
6\end{array}$ & $\begin{array}{r}4874.0 \\
7\end{array}$ & & & \\
\hline
\end{tabular}

\section{Cash Flow No.3: Cash Flow as per toll rates \& accepted tender form.}

Base99-0000-0101-0202-0303-0404-0505-0606-0707-0808-09

Rate of Interest $23 \% 18.40 \% 17.47 \% 14.72 \% 14.15 \% 13.84 \% 13.8 \% 13.8 \% 13.8 \% 13.84 \% 13.80 \%$ 09-1010-11 $11-12$

$13.8 \% \quad 14.12 \% 18.28 \%$

\begin{tabular}{|c|c|c|c|c|c|c|c|c|c|c|c|c|}
\hline \multicolumn{2}{|c|}{ Period } & \multirow[t]{2}{*}{$\begin{array}{l}\text { Yea } \\
\mathbf{r}\end{array}$} & \multicolumn{2}{|c|}{$\begin{array}{c}\text { Details of } \\
\text { Income }\end{array}$} & \multicolumn{5}{|c|}{ Details of Expenditure } & \multicolumn{3}{|c|}{ Cash flow details } \\
\hline From & To & & Toll & $\begin{array}{l}\text { Ad } \\
\text { v. }\end{array}$ & $\begin{array}{l}\text { Const. } \\
\text { Cost }\end{array}$ & $\begin{array}{l}\text { Intere } \\
\text { st }\end{array}$ & $\begin{array}{l}\text { M \& } \\
\text { R }\end{array}$ & $\begin{array}{l}\text { Opera } \\
\text { ting } \\
\text { Cost }\end{array}$ & $\begin{array}{l}\text { Total } \\
\text { expend } \\
\text { iture }\end{array}$ & $\begin{array}{l}\text { Net } \\
\text { Yearl } \\
\text { y } \\
\text { cash }\end{array}$ & $\begin{array}{l}\text { Outsta } \\
\text { nding } \\
\text { amou } \\
\text { nt }\end{array}$ & I R R \\
\hline
\end{tabular}




\begin{tabular}{|c|c|c|c|c|c|c|c|c|c|c|c|c|}
\hline & & & & & & & & & & flow & & \\
\hline 1 & 2 & 3 & 4 & 5 & 6 & 7 & 8 & 9 & 10 & 11 & & 13 \\
\hline $\begin{array}{c}23-03- \\
99 \\
\end{array}$ & $\begin{array}{c}22-03- \\
00\end{array}$ & 1 & 0.00 & $\begin{array}{c}0.0 \\
0 \\
\end{array}$ & $\begin{array}{c}375.0 \\
0\end{array}$ & 34.50 & 0.00 & 0.00 & 409.50 & $\begin{array}{c}- \\
409.5 \\
0\end{array}$ & $\begin{array}{c}409.5 \\
0 \\
\end{array}$ & $\begin{array}{c}\text { \#NU } \\
\mathrm{M} !\end{array}$ \\
\hline $\begin{array}{c}23-03- \\
00\end{array}$ & $\begin{array}{c}22-03- \\
01\end{array}$ & 2 & 0.00 & $\begin{array}{c}0.0 \\
0\end{array}$ & $\begin{array}{c}375.0 \\
0\end{array}$ & $\begin{array}{c}104.3 \\
0\end{array}$ & 0.00 & 0.00 & 479.30 & $\begin{array}{c}- \\
479.3 \\
0\end{array}$ & $\begin{array}{c}888.8 \\
0\end{array}$ & $\begin{array}{c}\text { \#NU } \\
\text { M! }\end{array}$ \\
\hline $\begin{array}{c}23-03- \\
01\end{array}$ & $\begin{array}{c}22-03- \\
02\end{array}$ & 3 & 243.92 & $\begin{array}{c}0.0 \\
0\end{array}$ & 0.00 & $\begin{array}{c}130.8 \\
3\end{array}$ & 11.25 & 42.00 & 184.08 & 59.84 & $\begin{array}{c}828.9 \\
6\end{array}$ & $\begin{array}{c}\text { \#NU } \\
\text { M! }\end{array}$ \\
\hline $\begin{array}{c}23-03- \\
02\end{array}$ & $\begin{array}{c}22-03- \\
03\end{array}$ & 4 & 256.08 & $\begin{array}{c}0.0 \\
0\end{array}$ & 0.00 & $\begin{array}{c}117.3 \\
0\end{array}$ & 12.38 & 46.20 & 175.87 & 80.21 & $\begin{array}{c}748.7 \\
5\end{array}$ & $-60 \%$ \\
\hline $\begin{array}{c}23-03- \\
03\end{array}$ & $\begin{array}{c}22-03- \\
04\end{array}$ & 5 & 268.9 & $\begin{array}{c}0.0 \\
0\end{array}$ & 0.00 & $\begin{array}{c}103.6 \\
3 \\
\end{array}$ & 13.61 & 50.82 & 168.06 & $\begin{array}{c}100.8 \\
4\end{array}$ & $\begin{array}{c}647.9 \\
1\end{array}$ & $-38 \%$ \\
\hline $\begin{array}{c}23-03- \\
04 \\
\end{array}$ & $\begin{array}{c}22-03- \\
05\end{array}$ & 6 & 332.09 & $\begin{array}{c}0.0 \\
0 \\
\end{array}$ & 0.00 & 89.41 & 14.97 & 55.90 & 160.29 & $\begin{array}{c}171.8 \\
0\end{array}$ & $\begin{array}{c}476.1 \\
1 \\
\end{array}$ & $-20 \%$ \\
\hline $\begin{array}{c}23-03- \\
05\end{array}$ & $\begin{array}{c}22-03- \\
06\end{array}$ & 7 & 348.69 & $\begin{array}{c}0.0 \\
0\end{array}$ & 0.00 & 65.70 & 66.47 & 61.49 & 193.67 & $\begin{array}{c}155.0 \\
2\end{array}$ & $\begin{array}{c}321.0 \\
8\end{array}$ & $-11 \%$ \\
\hline $\begin{array}{c}23-03- \\
06\end{array}$ & $\begin{array}{c}22-03- \\
07 \\
\end{array}$ & 8 & 366.13 & $\begin{array}{c}0.0 \\
0 \\
\end{array}$ & 0.00 & 44.31 & 18.12 & 67.64 & 130.07 & $\begin{array}{c}236.0 \\
6\end{array}$ & 85.02 & $\begin{array}{c}- \\
2.11 \% \\
\end{array}$ \\
\hline $\begin{array}{c}23-03- \\
07 \\
\end{array}$ & $\begin{array}{c}22-03- \\
08 \\
\end{array}$ & 9 & 442.04 & $\begin{array}{c}0.0 \\
0 \\
\end{array}$ & 0.00 & 11.77 & 19.93 & 74.41 & 106.10 & $\begin{array}{c}335.9 \\
4 \\
\end{array}$ & $\begin{array}{c}- \\
250.9 \\
2 \\
\end{array}$ & $4.68 \%$ \\
\hline $\begin{array}{c}23-03- \\
08 \\
\end{array}$ & $\begin{array}{c}22-03- \\
09 \\
\end{array}$ & 10 & 464.14 & $\begin{array}{c}0.0 \\
0 \\
\end{array}$ & 0.00 & 0.00 & 21.92 & 81.85 & 103.77 & $\begin{array}{c}360.3 \\
7 \\
\end{array}$ & $\begin{array}{c}- \\
611.2 \\
9 \\
\end{array}$ & $9.05 \%$ \\
\hline $\begin{array}{c}23-03- \\
09\end{array}$ & $\begin{array}{c}13-12- \\
10\end{array}$ & $\begin{array}{c}10.7 \\
3\end{array}$ & 355.05 & $\begin{array}{c}0.0 \\
0\end{array}$ & 0.00 & 0.00 & 97.56 & 65.59 & 163.15 & $\begin{array}{c}191.9 \\
0\end{array}$ & $\begin{array}{c}- \\
803.1 \\
8\end{array}$ & $\begin{array}{c}10.68 \\
\%\end{array}$ \\
\hline & & & $\begin{array}{c}3077.0 \\
4\end{array}$ & & $\begin{array}{c}750.0 \\
0\end{array}$ & $\begin{array}{c}701.7 \\
4\end{array}$ & $\begin{array}{c}276.2 \\
2\end{array}$ & $\begin{array}{c}545.9 \\
0\end{array}$ & $\begin{array}{c}2273.8 \\
6\end{array}$ & & & \\
\hline
\end{tabular}

\begin{tabular}{|c|c|c|}
\hline Sr No. & Particulars & \\
\hline 1 & $\begin{array}{l}\text { Arbitration Result for Claim I=amounting to Rs/- } 125.00 \text { lakhs in favour of } \\
\text { Entrepreneur has been challenged by Govt. vide Misc. Appl.at Hon. High court } \\
\text { hearing of the same is in progress Result is awaited }\end{array}$ & $\begin{array}{l}\quad \text { Toll Calculation } \\
487.35365 \\
1.335205479265 .91413\end{array}$ \\
\hline 2 & $\begin{array}{l}\text { Arbitration Result for Claim II=amounting to Rs/-120.00 lakhs in favour of } \\
\text { Govt.has been challenged by Entrepreneur. vide Misc. Appl. at Hon. Dist. } \\
\text { court hearing of the same is in progress Result is awaited }\end{array}$ & $\begin{array}{l}\text { Maintenance Cost } \\
24.11365 \\
0.06605479517 .564903 \\
\end{array}$ \\
\hline 3 & Claim for Bitumen Escalation amounting to RS/- 28.00 lakhs is under scrutiny & $\begin{array}{l}\quad \text { Operating cost } \\
90.03365 \\
0.24665753465 .589723\end{array}$ \\
\hline
\end{tabular}

\section{Cash Flow No.4: Cash Flow PLR + Claim}

Base 99-00 00-01 01-0202-03 03-04 04-05 05-06 06-07 07-08 08-09

Rate of Interest23\%18.40\%17.47\%14.72\%14.15\%13.84\%13.8\%13.8\%13.8\%13.84\%13.80\%

09-1010-11 $11-12$

$13.8 \% \quad 14.12 \% 18.28 \%$

\begin{tabular}{|c|c|c|c|c|c|c|c|c|c|c|c|c|}
\hline \multicolumn{2}{|c|}{ Period } & \multirow[t]{2}{*}{$\begin{array}{l}\mathbf{Y} \\
\mathbf{e} \\
\mathbf{a} \\
\mathbf{r}\end{array}$} & \multicolumn{2}{|c|}{$\begin{array}{l}\text { Details of } \\
\text { Income }\end{array}$} & \multicolumn{5}{|c|}{ Details of Expenditure } & \multicolumn{3}{|c|}{ Cash flow details } \\
\hline From & To & & Toll & $\begin{array}{l}\text { Adv } \\
\text { ertis } \\
\text { eme } \\
\text { nt }\end{array}$ & $\begin{array}{l}\text { Con } \\
\text { st. } \\
\text { Cost }\end{array}$ & $\begin{array}{l}\text { Inter } \\
\text { est }\end{array}$ & $\begin{array}{l}\mathrm{M} \& \\
\mathrm{R}\end{array}$ & $\begin{array}{l}\text { Ope } \\
\text { ratin } \\
\mathrm{g} \\
\text { Cost }\end{array}$ & $\begin{array}{l}\text { Total } \\
\text { expe } \\
\text { nditu } \\
\text { re }\end{array}$ & $\begin{array}{l}\text { Net } \\
\text { Yearl } \\
\text { y cash } \\
\text { flow }\end{array}$ & $\begin{array}{l}\text { Outst } \\
\text { andin } \\
\mathrm{g} \\
\text { amou } \\
\mathrm{nt}\end{array}$ & I R R \\
\hline 1 & 2 & 3 & 4 & 5 & 6 & 7 & 8 & 9 & 10 & 11 & & 13 \\
\hline $\begin{array}{c}23-03- \\
99\end{array}$ & $\begin{array}{c}22-03- \\
00\end{array}$ & 1 & 0.00 & 0.00 & $\begin{array}{c}437 . \\
50\end{array}$ & 40.25 & 0.00 & 0.00 & $\begin{array}{c}477.7 \\
5\end{array}$ & $\begin{array}{c}- \\
477.7\end{array}$ & $\begin{array}{c}477.7 \\
5\end{array}$ & $\begin{array}{c}\text { \#NU } \\
\text { M! }\end{array}$ \\
\hline
\end{tabular}




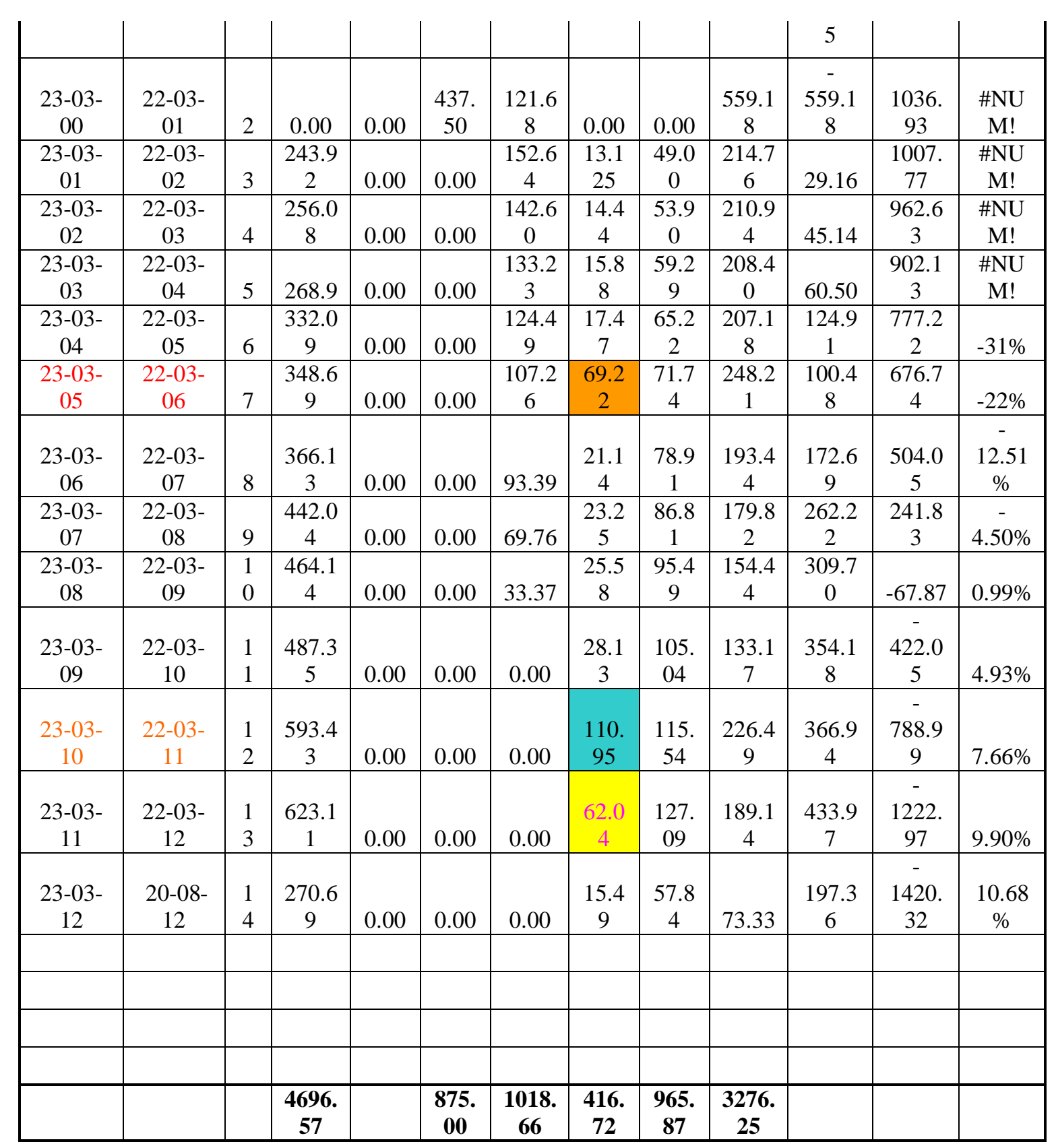

\begin{tabular}{|c|c|c|}
\hline $\begin{array}{c}\text { Sr } \\
\text { No. }\end{array}$ & Particulars & \\
\hline 1 & $\begin{array}{l}\text { Arbitration Result for Claim I=amounting to Rs/-125.00 lakhs in favour } \\
\text { of Entrepreneur has been challenged by Govt. vide Misc. Appl. at Hon. High } \\
\text { court hearing of the same is in progress Result is awaited(The amount is } \\
\text { considered at Cash flow) }\end{array}$ & $\begin{array}{l}\text { Toll Calculation } \\
654.26 \quad 365 \\
1.792493151 \\
151.031293\end{array}$ \\
\hline 2 & $\begin{array}{l}\text { Arbitration Result for Claim II=amounting to Rs/-120.00 lakhs in favour } \\
\text { of Govt. has been challenged by Entrepreneur. vide Misc. Appl. at Hon. Dist. } \\
\text { court hearing of the same is in progress Result is awaited(The amount is } \\
\text { not considered at Cash flow) }\end{array}$ & $\begin{array}{l}\quad \text { Maintenance Cost } \\
37.45365 \\
0.1026027415 .4943608\end{array}$ \\
\hline 3 & $\begin{array}{l}\text { Claim for Bitumen Escalation amounting to RS/- } 28.00 \text { lakhs is under } \\
\text { scrutiny Amount of the same is considered at cash flow at M\&R year } \\
2011-12\end{array}$ & $\begin{array}{l}\text { Operating cost } \\
139.80365 \\
0.38301369957 .84009721\end{array}$ \\
\hline
\end{tabular}


Table no.1: RBI Interest REPO

\begin{tabular}{|c|c|c|c|}
\hline Date & REPO & Date & REPO \\
\hline $20-10-2008$ & $8.00 \%$ & $04-07-1991$ & $11.00 \%$ \\
\hline $03-11-2008$ & $7.50 \%$ & $09-10-1991$ & $12.00 \%$ \\
\hline $08-12-2008$ & $6.50 \%$ & $16-04-1997$ & $11.00 \%$ \\
\hline $02-01-2009$ & $5.50 \%$ & $26-06-1997$ & $10.00 \%$ \\
\hline $04-09-2009$ & $5.00 \%$ & $22-10-1997$ & $9.00 \%$ \\
\hline $16-09-2010$ & $6.00 \%$ & $17-01-1998$ & $11.00 \%$ \\
\hline $02-11-2010$ & $6.25 \%$ & $19-03-1998$ & $10.80 \%$ \\
\hline $25-01-2011$ & $6.50 \%$ & $03-04-1998$ & $10.00 \%$ \\
\hline $17-03-2011$ & $6.75 \%$ & $29-04-1998$ & $9.00 \%$ \\
\hline $03-05-2011$ & $7.25 \%$ & $02-03-1999$ & $8.00 \%$ \\
\hline $16-06-2011$ & $7.50 \%$ & $02-04-2000$ & $7.00 \%$ \\
\hline $26-07-2011$ & $8.00 \%$ & $22-07-2000$ & $8.00 \%$ \\
\hline $16-09-2011$ & $8.25 \%$ & $17-02-2001$ & $7.50 \%$ \\
\hline $25-10-2011$ & $8.50 \%$ & $02-03-2001$ & $7.00 \%$ \\
\hline $17-04-2012$ & $8.00 \%$ & $23-10-2001$ & $6.50 \%$ \\
\hline & & $30-10-2002$ & $6.25 \%$ \\
\hline & & $30-04-2003$ & $6.00 \%$ \\
\hline
\end{tabular}

Name ofWork: Const.of Major Bridge across River and Bye pass outside City under B.O.T.

Table No.2:Rate of interest as per RBI Interest rate

Date of work order:--23-03-1999 Date of Tender receipt: -- 27-04-1998

\begin{tabular}{|c|c|c|c|c|c|c|c|c|c|c|}
\hline \multirow{2}{*}{$\begin{array}{c}\text { Ye } \\
\text { ar } \\
\\
\\
1 \\
\end{array}$} & \multicolumn{2}{|c|}{$\begin{array}{c}\text { Date } \\
\text { From } \\
\text { To }\end{array}$} & \multirow{2}{*}{$\begin{array}{l}\text { SBI } \\
\text { PL } \\
\text { R } \\
\\
4 \\
\end{array}$} & \multirow{2}{*}{$\begin{array}{l}\text { Rate of } \\
\text { interest } \\
\text { as per } \\
\text { Entrepr } \\
\text { eneur } \\
5 \\
\end{array}$} & \multicolumn{2}{|c|}{$\begin{array}{l}\text { Modified interest } \\
\text { as per PLR }\end{array}$} & \multirow{2}{*}{$\begin{array}{l}\text { Da } \\
\text { ys } \\
\\
8 \\
\end{array}$} & \multirow{2}{*}{$\begin{array}{l}\text { Days/ } \\
\mathbf{3 6 5} \\
\\
9 \\
\end{array}$} & \multirow{2}{*}{$\begin{array}{c}\text { Intere } \\
\text { st rate } \\
\text { Col 7x } \\
\text { Col } 9 \\
10 \\
\end{array}$} & \multirow{2}{*}{$\begin{array}{l}\text { Yearl } \\
\mathbf{y} \\
\text { inter } \\
\text { est } \\
\text { rate } \\
11 \\
\end{array}$} \\
\hline & 2 & 3 & & & 6 & 7 & & & & \\
\hline & & & & & & & & & & \\
\hline & $\begin{array}{l}26-04- \\
1998 \\
\end{array}$ & & $\begin{array}{l}10 . \\
00\end{array}$ & 23.00 & $\begin{array}{c}23.00 \times 10 / 10 \\
=\end{array}$ & $\begin{array}{l}23 . \\
00\end{array}$ & & & & \\
\hline 1 & $\begin{array}{l}23-03- \\
1999 \\
\end{array}$ & $\begin{array}{l}22-03- \\
2000\end{array}$ & $\begin{array}{c}8.0 \\
0\end{array}$ & 23.00 & $\begin{array}{c}23.00 \times 8 / 10 \\
=\end{array}$ & $\begin{array}{l}18 . \\
40 \\
\end{array}$ & 366 & 1.00 & 18.40 & 18.40 \\
\hline & & & & & & & 366 & 1.00 & 18.40 & 18.40 \\
\hline \multirow{5}{*}{2} & $\begin{array}{l}23-03- \\
2000\end{array}$ & $\begin{array}{l}22-07- \\
2000\end{array}$ & $\begin{array}{c}8.0 \\
0\end{array}$ & 23.00 & $\begin{array}{c}23.00 \times 8 / 10 \\
=\end{array}$ & $\begin{array}{l}18 . \\
40\end{array}$ & 122 & 0.33 & 6.15 & \multirow{4}{*}{17.47} \\
\hline & $\begin{array}{l}23-07- \\
2000\end{array}$ & $\begin{array}{l}17-02- \\
2001 \\
\end{array}$ & $\begin{array}{c}7.5 \\
0\end{array}$ & 23.00 & $\begin{array}{c}23.00 \times 7.50 / \\
10=\end{array}$ & $\begin{array}{l}17 . \\
25 \\
\end{array}$ & 210 & 0.58 & 9.92 & \\
\hline & $\begin{array}{l}18-02- \\
2001\end{array}$ & $\begin{array}{l}02-03- \\
2001\end{array}$ & $\begin{array}{c}7.0 \\
0\end{array}$ & 23.00 & $\begin{array}{c}23.00 \times 7.00 / \\
10=\end{array}$ & $\begin{array}{l}16 . \\
10 \\
\end{array}$ & 13 & 0.04 & 0.57 & \\
\hline & $\begin{array}{l}\text { 03-03- } \\
2001\end{array}$ & $\begin{array}{l}22-03- \\
2001\end{array}$ & $\begin{array}{c}6.5 \\
0\end{array}$ & 23.00 & $\begin{array}{c}23.00 \times 6.50 / \\
10=\end{array}$ & $\begin{array}{l}14 . \\
95\end{array}$ & 20 & 0.05 & 0.82 & \\
\hline & & & & & & & 365 & 1.00 & 17.47 & 17.47 \\
\hline \multirow{3}{*}{3} & $\begin{array}{l}23-03- \\
2001\end{array}$ & $\begin{array}{l}23-10- \\
2001\end{array}$ & $\begin{array}{c}6.5 \\
0 \\
\end{array}$ & 23.00 & $\begin{array}{c}23.00 \times 6.50 / \\
10=\end{array}$ & $\begin{array}{l}14 . \\
95 \\
\end{array}$ & 215 & 0.59 & 8.81 & \multirow{2}{*}{14.72} \\
\hline & $\begin{array}{l}24-10- \\
2001\end{array}$ & $\begin{array}{l}22-03- \\
2002\end{array}$ & $\begin{array}{c}6.2 \\
5\end{array}$ & 23.00 & $\begin{array}{c}23.00 \times 6.25 / \\
10=\end{array}$ & $\begin{array}{l}14 . \\
38 \\
\end{array}$ & 150 & 0.41 & 5.91 & \\
\hline & & & & & & & 365 & 1.00 & 14.72 & 14.72 \\
\hline \multirow{3}{*}{4} & $\begin{array}{l}23-03- \\
2002\end{array}$ & $\begin{array}{l}31-10- \\
2002\end{array}$ & $\begin{array}{c}6.2 \\
5\end{array}$ & 23.00 & $\begin{array}{c}23.00 \times 6.25 / \\
10=\end{array}$ & $\begin{array}{l}14 . \\
38 \\
\end{array}$ & 223 & 0.61 & 8.78 & \multirow{2}{*}{14.15} \\
\hline & $\begin{array}{l}01-11- \\
2002\end{array}$ & $\begin{array}{l}22-03- \\
2003\end{array}$ & $\begin{array}{c}6.0 \\
0\end{array}$ & 23.00 & $\begin{array}{c}23.00 \times 6.00 / \\
10=\end{array}$ & $\begin{array}{l}13 . \\
80\end{array}$ & 142 & 0.39 & 5.37 & \\
\hline & & & & & & & 365 & 1.00 & 14.15 & 14.15 \\
\hline
\end{tabular}


Risk Assessment of BOT Road Projects

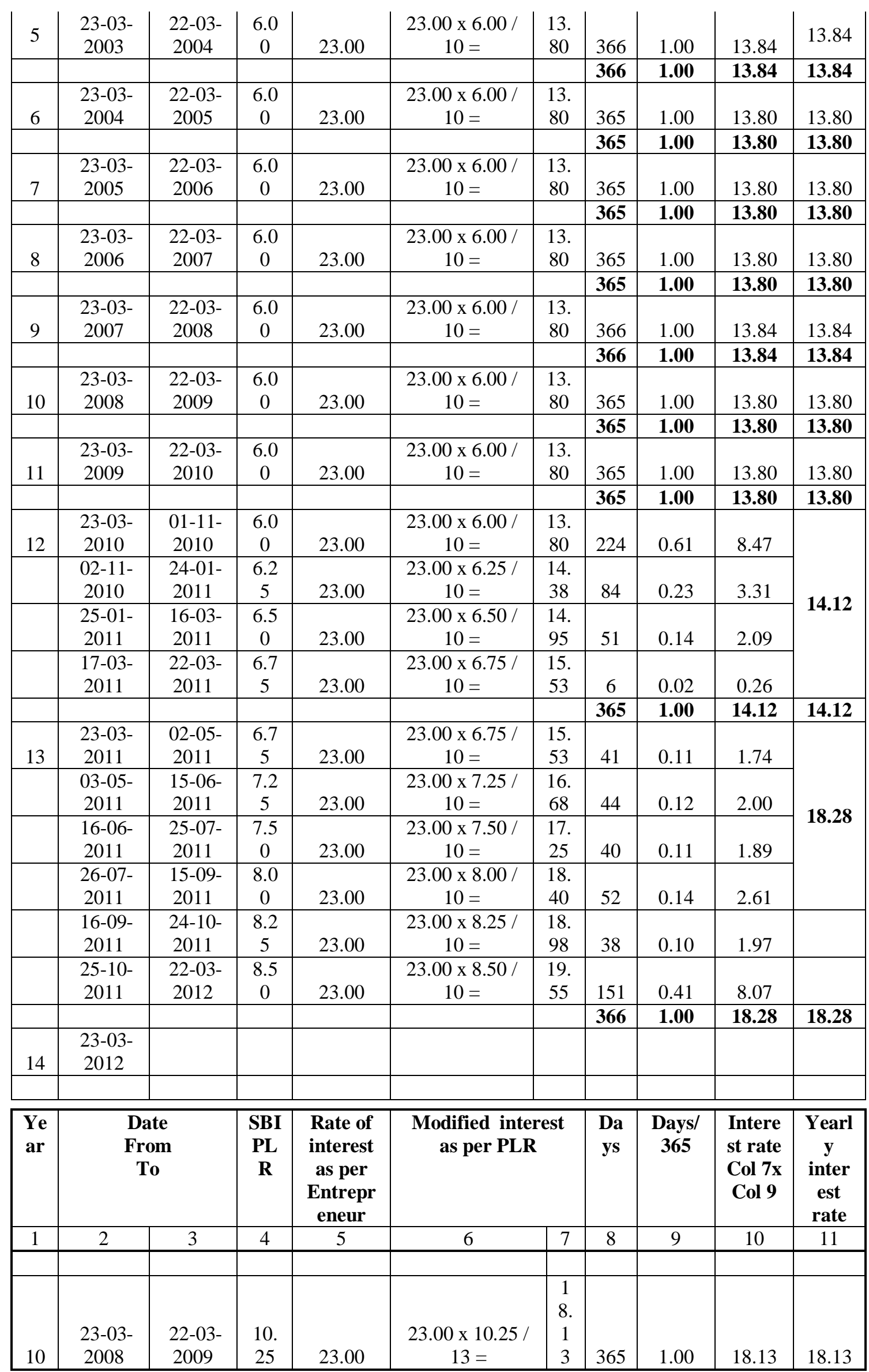




\begin{tabular}{|c|c|c|c|c|c|c|c|c|c|c|}
\hline & & & & & & & 365 & & & 18.13 \\
\hline 11 & $\begin{array}{l}23-03- \\
2009\end{array}$ & $\begin{array}{l}22-03- \\
2010\end{array}$ & $\begin{array}{l}10 . \\
25\end{array}$ & 23.00 & $\begin{array}{c}23.00 \times 10.25 / \\
13=\end{array}$ & $\begin{array}{l}1 \\
8 . \\
1 \\
3\end{array}$ & 365 & 1.00 & 18.13 & 18.13 \\
\hline & & & & & & & 365 & & & 18.13 \\
\hline 12 & $\begin{array}{l}23-03- \\
2010\end{array}$ & $\begin{array}{l}22-03- \\
2011\end{array}$ & $\begin{array}{l}10 . \\
25\end{array}$ & 23.00 & $\begin{array}{c}23.00 \times 10.25 / \\
13=\end{array}$ & $\begin{array}{l}1 \\
8 . \\
1 \\
3\end{array}$ & 365 & 1.00 & 18.13 & 18.13 \\
\hline & & & & & & & 365 & & & 18.13 \\
\hline 13 & $\begin{array}{l}23-03- \\
2011\end{array}$ & $\begin{array}{l}22-03- \\
2012\end{array}$ & $\begin{array}{l}10 . \\
25\end{array}$ & 23.00 & $\begin{array}{c}23.00 \times 10.25 / \\
13=\end{array}$ & $\begin{array}{l}1 \\
8 . \\
1 \\
3\end{array}$ & 365 & 1.00 & 18.13 & 18.13 \\
\hline & & & & & & & 365 & & & 18.13 \\
\hline 14 & $\begin{array}{l}23-03- \\
2012\end{array}$ & $\begin{array}{l}22-03- \\
2013\end{array}$ & $\begin{array}{l}10 . \\
25\end{array}$ & 23.00 & $\begin{array}{c}23.00 \times 10.25 / \\
13=\end{array}$ & $\begin{array}{l}1 \\
8 . \\
1 \\
3\end{array}$ & 365 & 1.00 & 18.13 & 18.13 \\
\hline & & & & & & & 365 & & & 18.13 \\
\hline 15 & $\begin{array}{l}23-03- \\
2013\end{array}$ & $\begin{array}{l}22-03- \\
2014\end{array}$ & $\begin{array}{l}10 . \\
25\end{array}$ & 23.00 & $\begin{array}{c}23.00 \times 10.25 / \\
13=\end{array}$ & $\begin{array}{c}1 \\
8 . \\
1 \\
3\end{array}$ & 365 & 1.00 & 18.13 & 18.13 \\
\hline & & & & & & & 365 & & & $\overline{18.13}$ \\
\hline 16 & $\begin{array}{l}23-03- \\
2014 \\
\end{array}$ & $\begin{array}{l}22-03- \\
2015 \\
\end{array}$ & $\begin{array}{l}10 . \\
25 \\
\end{array}$ & 23.00 & $\begin{array}{c}23.00 \times 10.25 / \\
13=\end{array}$ & $\begin{array}{c}1 \\
8 . \\
1 \\
3 \\
\end{array}$ & 365 & 1.00 & 18.13 & 18.13 \\
\hline & & & & & & & 365 & & & 18.13 \\
\hline
\end{tabular}

\section{Conclusion}

As a conclusion, risk management is an important process necessary in order to achieve a successful project financing... The case study describes the project background, the project contractor, the financing of the project, the risk involved in each phase; the method used to limit the risks, the problems encountered the current status of the projects, as well as an overall assessment of the success or failure of the project.

A BOT project is affected by various options relating to the toll structure, toll revision schedule, extent of government grant, and the duration of the concession period. This paper described facilitates the study of the financial viability of a BOT project as affected by the concession period, as demonstrated by the case study. By careful consideration of the results of the simulation study, the project sponsor and the project promoter can arrive at a reasonable agreement on the sharing of risks and the terms of the concession.

Various Categories,Phases, Risk Identification, Risk Mitigation are as follows ...

\begin{tabular}{|l|l|l|l|}
\hline $\begin{array}{l}\text { RISK } \\
\text { CATEGORY }\end{array}$ & $\begin{array}{l}\text { PHASEOF } \\
\text { PREDOMIN } \\
\text { ANCE }\end{array}$ & $\begin{array}{l}\text { RISK } \\
\text { IDENTIFICATION }\end{array}$ & RISK MITIGATION \\
\hline Land Acquisition & $\begin{array}{l}\text { Project } \\
\text { Development }\end{array}$ & $\begin{array}{l}\text { Delays in land acquisition and in } \\
\text { providing encumbered right of } \\
\text { way to the EPC contractor can } \\
\text { lead to delays in the start of } \\
\text { construction resulting in } \\
\text { escalation of project cost } \\
\text { Additionally, the risk of cost of } \\
\text { acquisition not be in contained } \\
\text { within the estimates. }\end{array}$ & $\begin{array}{l}\text { Timely provision of land for } \\
\text { construction of facilities and systems } \\
\text { should be made a condition precedent to } \\
\text { bease/concession Agreement. } \\
\text { clearances, the government should grant } \\
\text { necessary permissions and the same } \\
\text { should be executed within specified time. } \\
\text { c) On delay, the concession period should } \\
\text { be extended by an equal period }\end{array}$ \\
\hline $\begin{array}{l}\text { Project } \\
\text { Completion Risk }\end{array}$ & $\begin{array}{l}\text { Construction } \\
\text { Period }\end{array}$ & $\begin{array}{l}\text { The project completion risk or } \\
\text { the contractor's risk refers to the } \\
\text { possibility of non-completion of }\end{array}$ & $\begin{array}{l}\text { This risk should be mitigated through a } \\
\text { Provision under Concession Contract (CC) } \\
\text { CC with EPC contractor to include }\end{array}$ \\
\hline
\end{tabular}




\begin{tabular}{|c|c|c|c|}
\hline & & $\begin{array}{l}\text { the project with the designated } \\
\text { period from the Notice to } \\
\text { Proceed. Any delays in the } \\
\text { construction may be expected to } \\
\text { result in increased construction } \\
\text { costs. }\end{array}$ & $\begin{array}{l}\text { turnkey, fixed price design \& construction } \\
\text { contract with payments made on reaching } \\
\text { certain milestones } \\
\text { Contractor to pay Liquidated Damages for } \\
\text { delays during construction } \\
\text { Independent Engineer should review and } \\
\text { monitor progress }\end{array}$ \\
\hline Technology Risk & $\begin{array}{l}\text { Construction/ } \\
\text { Operation } \\
\text { period }\end{array}$ & $\begin{array}{l}\text { This pertains to the risk that the } \\
\text { project may be either physically } \\
\text { inappropriate to handle the } \\
\text { projected demand or is } \\
\text { inappropriately designed to meet } \\
\text { local socio-economic needs and } \\
\text { hence rectification of these } \\
\text { design could escalate the O\&M } \\
\text { costs during the operations } \\
\text { period }\end{array}$ & $\begin{array}{l}\text { the project to be designed after a } \\
\text { comprehensive analysis of the local } \\
\text { conditions } \\
\text { the construction should be carried out with } \\
\text { strict penalties for noncompliance of the } \\
\text { technical design by the contractor }\end{array}$ \\
\hline $\begin{array}{l}\text { Operations and } \\
\text { Maintenance risk }\end{array}$ & $\begin{array}{l}\text { Operation } \\
\text { period }\end{array}$ & $\begin{array}{l}\text { In the event of O\&M costs } \\
\text { exceeding the estimates used for } \\
\text { the establishment of financial } \\
\text { viability, residual cash flows for } \\
\text { debt/equity services would be } \\
\text { lower than anticipated there by } \\
\text { affecting project returns. }\end{array}$ & $\begin{array}{l}\text { Selection of O\&M operator will be on the } \\
\text { basis of competitive bidding the selection } \\
\text { criteria should take into account of its past } \\
\text { record, fiduciary responsibility exhibited } \\
\text { in other assignment, financial strength etc. } \\
\text { The O\&M contract should provide for a } \\
\text { fixed \& a variable fee which could be } \\
\text { based upon the O\&M requirements set } \\
\text { forth in the Concession Agreement. } \\
\text { O\&M Contract is a fixed price contract, } \\
\text { with risk of cost over-runs to be borne by } \\
\text { the O\&M Contractor. }\end{array}$ \\
\hline \multicolumn{4}{|l|}{ Financial Risk } \\
\hline $\begin{array}{l}\text { Interest Rate } \\
\text { Risk }\end{array}$ & $\begin{array}{l}\text { Operations } \\
\text { Period }\end{array}$ & $\begin{array}{l}\text { Determination of project } \\
\text { viability is predicated on the } \\
\text { existing interest rate scenario } \\
\text { prevailing in the country. A } \\
\text { drastic increase in the interest } \\
\text { rate scenario may affect the debt } \\
\text { servicing capability through } \\
\text { project cash flows and } \\
\text { significantly depress shareholder } \\
\text { returns, even though the project } \\
\text { may still achieve the designated } \\
\text { return }\end{array}$ & $\begin{array}{l}\text { The project should be financed on an } \\
\text { optimal mix of fixed rate and floating rate } \\
\text { instruments, to hedge the interest rate } \\
\text { movement risk }\end{array}$ \\
\hline Inflation Risk & $\begin{array}{l}\text { Operation } \\
\text { period }\end{array}$ & $\begin{array}{l}\text { The tariff rates being inflation } \\
\text { indexed, the projected revenues } \\
\text { and consequently the } \\
\text { achievement of the designated } \\
\text { rate of return would be adversely } \\
\text { affected in case the inflation rate } \\
\text { is lower than what has been } \\
\text { assumed in the financial model }\end{array}$ & $\begin{array}{l}\text { Tariffs to be adjusted for inflation during } \\
\text { operations as per formulae given in the } \\
\text { concession agreement }\end{array}$ \\
\hline Force Majeure & $\begin{array}{l}\text { Throughout } \\
\text { project cycle }\end{array}$ & $\begin{array}{l}\text { This risk category deals with } \\
\text { nonpolitical events of force } \\
\text { majeure considered as "Acts of } \\
\text { god "such as epidemics, natural } \\
\text { disaster, earthquake, floods } \\
\text { during construction phase } \\
\text { affecting construction and such } \\
\text { other events. The impact of these } \\
\text { risks on construction and/or the } \\
\text { project operations could range } \\
\text { from minor to server, say in case } \\
\text { of earthquake, where the damage } \\
\text { may be server enough to render } \\
\text { the facilities irreparable }\end{array}$ & $\begin{array}{l}\text { Comprehensive insurance coverage } \\
\text { In force majeure risks of types which are } \\
\text { not insurable, the investors should get } \\
\text { yield of certain percentage on equity on } \\
\text { date of termination }\end{array}$ \\
\hline Social risks & Throughout & This is a risk that civil/political & Appropriate insurance package for the \\
\hline
\end{tabular}




\begin{tabular}{|l|l|l|l|}
\hline project cycle & $\begin{array}{l}\text { problems may surface as a result } \\
\text { of project, manifesting in } \\
\text { boycotts, sabotage etc. Such } \\
\text { disturbances may arrive from a } \\
\text { number of different concerns, } \\
\text { public objection to imposition of } \\
\text { tariff publicdiscontent with the } \\
\text { environmental impact of civil } \\
\text { work or other features of the } \\
\text { project an event similar to any of } \\
\text { above could impair the ability of } \\
\text { the concessionaire to collect } \\
\text { revenue thereby affecting project } \\
\text { viability. }\end{array}$ \\
\hline
\end{tabular}

\section{References}

[1] Caltrans, 2002, “Caltrans Project Management Handbook”, Caltrans Office of Project Management Process Improvement.

[2] Cooper D., Grey S., Raymond G., Walker P., 2005, "Project Risk Management Guidelines - Managing Risk in Large Projects and Complex Procurements", John Wile and Sons ltd. Publication.

[3] Dr.Khanna S.K., Dr.Justo C.E.G., 2001, Highway Engineering, New Chand Publication, Roorkee, $18^{\text {th }}$ Edn.

[4] Flanagan R., Norman G., 1993, "Risk Management and Construction”, Blackwell Science Ltd. Publication.

[5] GregariousG.N., 2007, "Advances in Risk Management", Palgrave McMillan.

[6] Gupta P.C., Venkatnarayan K., 2010, “An overview of dispute resolution procedures in road projects with reference to the FIDIC form of contract and suggestions for improvements”, journal of Indian Road Congress, Paper No.559, pp.101 - 110

[7] Kim H.J., Reinschmidt K.F., 2011, "Effects of Contractors Risk Attitude on Competition in Construction", ASCE journal of Construction Engineering and Management, Volume 137 (4), pp 175 - 183

[8] Laryea S., Hughes W., 2011, "Risk and Price in the Bidding Process of Contractors", ASCE journal of Construction Engineering and Management, Volume 137 (4), pp 248-258.

[9] Lexy S.N., "Build, Operate, Transfer", John Wiley and Sons, New York.

[10] P.W.D.Government of Maharashtra, 1978 - 2005, Compendium of Govt / circulars / Standard instructions regarding privatization of works of 'Road, Bridges, Building.

[11] Ramakrisnan R., 2010, "Ensure Professional Project Execution - A Contractor's Perspective”, The Indian Concrete Journal, pp. 3741

\section{Authors Bio Data:}

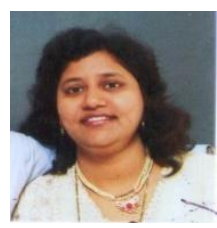

Rinaj M. Pathan obtained bachelor of engineering in civil from Shivaji University, Kolhapur in Maharashtra in 1994. She has been selected as Class I Officer in Engineering MPSC. Since last two years she is a student of the post graduate programme at construction and management, Deptartment. of Civil Engineering, Maharashtra institute of technology, Pune, India.

Her research interest is in construction materialtesting,infrastructuraldevelopment, BOT\& project management.

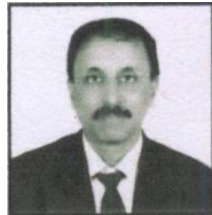

Dr. S. S. Pimplikar is presently professor \& head of the Department of Civil Engineering, Maharashtra Institute of Technology, Pune, India.

His subject areas in which he is teaching are: project management, new construction materials, accident studies, statistical methods, estimation \& tendering \& financial management.

His research interest is in construction material, transport engineering, green building and project management. Presented papers in international conferences and publish technical papers. He is a member of the Indian road congress, Indian society of hydraulics\& Indian society of technical Education. 